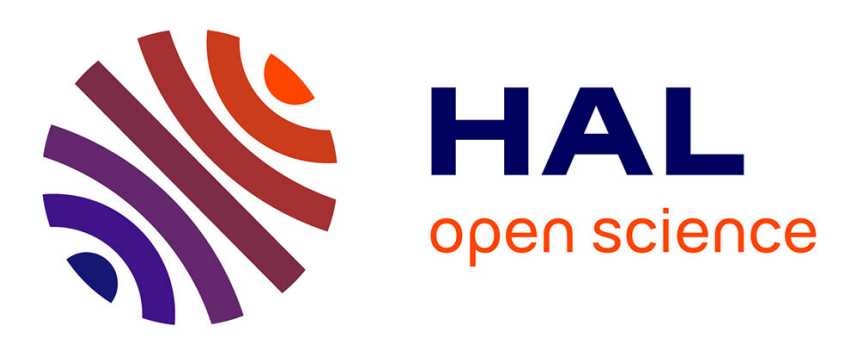

\title{
Hedonic evaluation of coral reef fish prices on a direct sale market
}

\author{
A. Nassiri, O. Thébaud, M. Lauer, S. J. Holbrook, A. Rassweiler, R. J. \\ Schmitt, Joachim Claudet
}

\section{- To cite this version:}

A. Nassiri, O. Thébaud, M. Lauer, S. J. Holbrook, A. Rassweiler, et al.. Hedonic evaluation of coral reef fish prices on a direct sale market. Marine Policy, 2021, 129, pp.104525. 10.1016/j.marpol.2021.104525 . hal-03212908

\section{HAL Id: hal-03212908 \\ https://hal.science/hal-03212908}

Submitted on 30 Apr 2021

HAL is a multi-disciplinary open access archive for the deposit and dissemination of scientific research documents, whether they are published or not. The documents may come from teaching and research institutions in France or abroad, or from public or private research centers.
L'archive ouverte pluridisciplinaire HAL, est destinée au dépôt et à la diffusion de documents scientifiques de niveau recherche, publiés ou non, émanant des établissements d'enseignement et de recherche français ou étrangers, des laboratoires publics ou privés. 


\section{Hedonic evaluation of coral reef fish prices on a direct sale market}

Nassiri A. ${ }^{1}$, Thébaud O. ${ }^{2}$, Holbrook, S.J. ${ }^{3}$, Lauer M. ${ }^{4}$, Rassweiler, A. ${ }^{5}$, Schmitt, R.J. ${ }^{6}$ and Claudet J. ${ }^{7,8}$

${ }^{1}$ UBO, CNRS, UMR 6308, AMURE, Unité d'Economie Maritime, IUEM, F-29280, Plouzané, France. Email: abdelhak.nassiri@univ-brest.fr

${ }^{2}$ Ifremer, UBO, CNRS, UMR 6308, AMURE, Unité d'Economie Maritime, IUEM, F-29280, Plouzane, France

${ }^{3}$ Department of Ecology, Evolution and Marine Biology and the Marine Science Institute, University of California Santa Barbara, Santa Barbara, CA 93106 USA https://orcid.org/00000002-3015-3484

${ }^{4}$ San Diego State University, Department of Anthropology, 5500 Campanile Drive, San Diego, CA 92182, USA

${ }^{5}$ Florida State University, Department of Biological Science, 319 Stadium Drive, Tallahassee, FL 32306, USA, https://orcid.org/0000-0002-8760-3888

${ }^{6}$ Department of Ecology, Evolution and Marine Biology and the Marine Science Institute, University of California Santa Barbara, Santa Barbara, CA 93106 USA https://orcid.org/00000002-0674-4244

${ }^{7}$ National Center for Scientific Research, PSL Université Paris, CRIOBE, USR 3278 CNRSEPHE-UPVD, Maison des Océans, Paris, FranceFrance

${ }^{8}$ Laboratoire d'excellence CORAIL, Moorea, French Polynesia 


\section{Introduction}

World-wide, coral reefs support small-scale subsistence fisheries (Cinner 2014). These are particularly important in the South Pacific, where coastal communities are strongly dependent on reef fisheries (Leenhardt et al. 2016; Rassweiler et al. 2020). The subsistence nature of these fisheries has often led to the assumption that, with the exception of export-oriented fisheries, their dynamics and the associated trade in fish products cannot be fully explained by standard market behavior (Léopold, Thébaud, et Charles 2019). Indeed, the existing social science research on coral reef fin-fish fisheries in the Pacific is largely focused on their ethnographical and sociological characteristics and non-market determinants of their evolution (Johannes 1981; Lauer et Aswani 2009; Audras, Bambridge, et Gaulme 2017). (but see Cinner et al. 2007).

Here, we will show how an economic analysis can help explain the patterns of fish sales and fish prices in a coral reef fin-fish fishery without centralized market. We assess the extent to which different taxa of reef fish attract different prices, reflecting relative supply and demand characteristics. In order to highlight such pricing strategies, we use data from a survey of fish sales on the island of Moorea, French Polynesia. Fishing plays an important role on Moorea, as a source of food for the local population, of income for fishers, and as an important aspect of Polynesian cultural identity (McManus 1997; Rassweiler et al. 2020). The majority (58\%) of the fish landed are taken from the lagoon (Yonger 2002), and a fraction of these are sold in lots called tuis. Each tui is composed of individuals of one or several different species of fish, tied together in strings of varying length. This local market is composed of multiple outlets along the island's coastal road, where fishers present their landings (tuis hanging from a rack) and consumers come to buy fresh fish (Leenhardt et Moussa 2012; Moussa 2010; Rassweiler et al. 2020). Both fish buyers and sellers are sensitive to the quality of the fish offered for sale. They also have a good knowledge of the value of each species, and of the value of tuis composed of different species as well as the distribution of prices across outlets. Therefore, the willingness 
of buyers to pay for an additional quantity or quality of a species of fish is likely to be equivalent to the costs that a fisher would incur to provide it, which should also equal the value that they expect to derive from the market.

To identify fish pricing strategies, we apply a hedonic modelling approach which accounts for different sources of price heterogeneity. With the required precautions, using the principle of revealed preferences (Rosen 1974), this method enables estimation of the implicit price of a non-marginal variation in the length (taken as a measure of the quantity) of individual groups of fish species, based on the price of the tui composed of these species groups. Indeed, fish buyers pay a price based on their knowledge of the species groups that compose the tui: their preference for each species group is thus expressed as a monetary amount equivalent to their willingness to pay to acquire an additional quantity of this species group.

Our analysis demonstrates how applied economic methods can be used to elicit the relative economic value of different species of reef fish landed in a small-scale fishery. Estimates of the market value of species groups frequently observed in tuis in Moorea reveal that implicit prices of fish may vary by a factor of four to five across species groups. These prices are affected by the origin of the catch and fishing techniques used. The results, derived from the fraction of catch that is sold, may be used as a guide to assessing the economic stakes associated with changes in the composition of catches in the broader, subsistence-oriented and non-market components of the fishery. The results may also help inform the design of management strategies for the fishery, taking into account economic drivers of fishing pressure on this local market. Beyond the fishery under study, the results also highlight the relevance of empirical economic analysis to improve the understanding of small-scale coral-reef fisheries in the Pacific, and demonstrate a methodology to investigate the economic stakes associated with changes in the structure of their production, which could be applied across a broad range of contexts. 


\section{Context and Data: Tui Sales on the Island of Moorea, French}

\section{Polynesia}

Coral reef fishing is a key activity for the coastal communities of French Polynesia. On the island of Moorea, fishing is strongly embedded in the livelihood and lifestyle of the local population, with most households engaged in a fishery-related activity (Leenhardt et al. 2016; Rassweiler et al. 2020; Thiault et al. 2017). A fraction of the landings of Moorea's small-scale fishery is sold along the roadside, generally close to the fisher's home in the form of strings of fish called tuis. The prices of individual tuis are observed through direct surveying of the sellers. Tui composition varies significantly, being made up of the same species or a mix of species, and of variable numbers of fishes of different sizes.

Tui prices and composition were surveyed on Moorea during 2014 and 2015 along the $60 \mathrm{~km}$ ring road. The survey documented the price of tuis sold. The species composition and sizes of fish on each tui were determined from photographs taken of each seller's rack at the time of the survey, with fish lengths calculated based on comparison with a scale bar of known size (see Rassweiler et al. 2020). Over the two years, 12002 individual fishes were measured, of which there were 8568 records with complete information, incorporated in 742 tuis sold by 164 sellers $^{1}$ and the majority of these $(79.88 \%)$ are the fishers themselves. The mean number of tuis observed $^{2}$ per seller on a given day was 4 to 5 , with a maximum of 23 , and half of the sellers were selling 3 tuis or more. Fish on each tui were identified taxonomically from the photographs with variable levels of precision (usually to genus or species). The identified taxa were aggregated into 37 functional groups (here called species groups). Parrotfish that had been noted as potentially belonging to two or more taxa (e.g., Scarus/Chlorurus) were assumed to belong

\footnotetext{
${ }^{1} 559$ tuis sold by 123 fishers in 2014, and 183 tuis sold by 41 fishers in 2015 .

${ }^{2}$ This was the number observed at the moment of sampling, so in certain cases, may be an underestimate of the total number of tuis offered for sale by a seller each day, as some tuis may already have been sold.
} 
to the first group listed. A range of non-reef taxa were aggregated within a group designated "pelagic" (Cheilopogon, Coryphaena, Cypselurus, Katsuwonus, Sarda, Scombridae, Thunnus).

A large number of the observed tuis were composed of single-species groups: 360 out of 742 . Multi-species group tuis were composed on average of 3 different species groups, and rarely contained more than 7 .

The resulting database contains three dimensions: the tui $t$ of seller $i$ composed of several species groups $j$. Table 1 provides summary statistics on the composition of the observed tuis. The data reveal that some species groups are commonly encountered in a majority of the recorded tuis with consistent lengths offered across multiple sellers. Indeed, the total length of fish offered with the first fourteen species groups (in grey) in Table 1 represents the vast majority $\left(95.85 \%, 4^{\text {th }}\right.$ column) of the total length of available fish across all the recorded tuis. Other species groups are more rarely encountered, and they appear in a limited number of tuis presented by some sellers. Within the same tui, the number and size of the fish pieces are negatively correlated $(-37.3 \%$ being the correlation coefficient) and the species groups most frequently encountered consist of smaller fish. The median length is about $22 \mathrm{~cm}$ for the four most frequent species groups and $26 \mathrm{~cm}$ for the others.

According to these observations, the prices of the 742 tuis vary by $482^{3 \mathrm{a}} \mathrm{CFP}^{4}$ around an average of $1773^{3 \mathrm{~b}} \mathrm{CFP}$ and their lengths by $106^{3 \mathrm{a}} \mathrm{cm}$ around an average length of $249^{3 \mathrm{~b}} \mathrm{~cm}$. These tuis are characterized by substantial heterogeneity along several dimensions, particularly with respect to their species-group composition. Almost half of the sample (361 tuis out of 742) is composed of single-species groups, corresponding to $42 \%$ of the total length of fish sold on this market by three quarters of the sellers (118 out of 164). These single-species tuis are composed of 21 of the 37 species groups recorded in roadside sales. The survey of 742 tuis

\footnotetext{
${ }^{3} \mathrm{a}=$ Standard deviation and $\mathrm{b}=$ Average

${ }^{4}$ The local currency is the Pacific Franc, Compagnie Française du Franc: $1 \mathrm{CFP}=0.008380$ Euro as of March 2021.
} 
includes both species groups characterized by smaller- (Acanthurus, Siganus and Myripristis) and larger-bodied (Epinephelus and Naso) fish, between 16 and $39 \mathrm{~cm}$ each. The prices of these tuis vary across species groups and sellers from 850 CFP to 2000 CFP, around an average price of 1620 CFP (Standard deviation, SD=594 CFP). The lengths of all fish offered on individual tuis also vary greatly with a $107 \mathrm{~cm}$ standard deviation around an average length of $216 \mathrm{~cm}$. It should be noted that price and length variations are positively correlated, but these correlations are weak between tuis $(27.37 \%)$ as well as between species groups ${ }^{5}(13.75 \%$ the correlation coefficient). Therefore, price variations among tuis and among species groups are not a simple function of the number or total length of fish on each tui.

\footnotetext{
${ }^{5}$ Correlation is calculated with the length and the price of the 118 single-species groups (Table 2).
} 
Table 1. Characteristics of the tuis observed in the survey

\begin{tabular}{|c|c|c|c|c|c|c|c|c|c|c|c|c|c|}
\hline $\begin{array}{l}\text { Species group j } \\
\text { (by decreasing } \\
\text { number of tuis) }\end{array}$ & $\begin{array}{l}\text { Num. } \\
\text { of. } \\
\text { sellers }\end{array}$ & $\begin{array}{l}\text { Num. } \\
\text { of tuis }\end{array}$ & $\begin{array}{l}\text { \% of tuis in } \\
\text { sample } \\
\text { containing } \\
\text { each species } \\
\text { group } \\
\end{array}$ & $\begin{array}{l}\text { Num. of other } \\
\text { species groups } \\
\text { present in tuis } \\
\text { sold by seller }\end{array}$ & $\begin{array}{l}\text { Total Length } \\
\text { of each species } \\
\text { group }(\mathrm{cm})\end{array}$ & $\begin{array}{l}\text { \% of } \\
\text { Total } \\
\text { Length in } \\
\text { sample }\end{array}$ & $\begin{array}{l}\text { Average Length } \\
\text { of species group } \\
\mathbf{j} \text { in single tuis } \\
\text { (cm) }\end{array}$ & $\begin{array}{l}\text { SD Length of } \\
\text { species group } \\
\text { j in single tuis } \\
(\mathrm{cm})\end{array}$ & $\begin{array}{l}\text { Average } \\
\text { Price of a } \\
\text { tui (CFP) }\end{array}$ & $\begin{array}{l}\text { SD } \\
\text { Price of } \\
\text { a tui } \\
\text { (CFP) }\end{array}$ & $\begin{array}{l}\text { Average Length } \\
\text { of fish of species } \\
\text { group } \mathbf{j}(\mathrm{cm})\end{array}$ & $\begin{array}{l}\text { SD Length of } \\
\text { fish of species } \\
\text { group } \mathbf{j}(\mathrm{cm})\end{array}$ & $\begin{array}{l}\text { CIG (Index } \\
\text { of ciguatera } \\
\text { risk } \\
\text { absence) }\end{array}$ \\
\hline Scarus & $114^{\mathrm{a}}$ & $311^{\mathrm{b}}$ & $42 \%^{\mathrm{e}}$ & $27^{j}$ & 57734 & $31.2 \%$ & 186 & 109 & 1926 & 246 & 23 & 5 & 100 \\
\hline Chlorurus & $78^{\mathrm{c}}$ & $140^{\mathrm{d}}$ & $19 \%{ }^{\mathrm{f}}$ & 21 & 9813 & $5.30 \%$ & 70 & 66 & 1900 & 301 & 24 & 6 & 100 \\
\hline Parupeneus & 81 & 130 & $18 \%$ & 25 & 11121 & $6.01 \%$ & 86 & 67 & 1919 & 247 & 23 & 4 & 100 \\
\hline Myripristis & 59 & 115 & $15 \%$ & 28 & 18924 & $10.2 \%$ & 165 & 117 & 1939 & 249 & 19 & 3 & 100 \\
\hline Mulloidichthys & 75 & 108 & $15 \%$ & 27 & 11737 & $6.34 \%$ & 109 & 88 & 1898 & 296 & 22 & 4 & 100 \\
\hline Siganus & 55 & 104 & $14 \%$ & 24 & 15609 & $8.43 \%$ & 150 & 104 & 1952 & 215 & 19 & 3 & 100 \\
\hline Pelagic & 20 & 90 & $12 \%$ & 4 & 15739 & $8.51 \%$ & 175 & 76 & 864 & 549 & 30 & 13 & 100 \\
\hline Naso & 49 & 85 & $11 \%$ & 21 & 6760 & $3.65 \%$ & 80 & 71 & 1929 & 269 & 28 & 13 & 100 \\
\hline Epinephelus & 53 & 73 & $10 \%$ & 22 & 8698 & $4.70 \%$ & 119 & 136 & 1986 & 117 & 22 & 5 & 75 \\
\hline Acanthurus & 43 & 58 & $8 \%$ & 21 & 6427 & $3.47 \%$ & 111 & 108 & 1922 & 226 & 19 & 4 & 100 \\
\hline Cephalopholis & 46 & 55 & $7 \%$ & 21 & 2567 & $1.39 \%$ & 47 & 29 & 2000 & 0 & 21 & 5 & 67 \\
\hline Sargocentron & 37 & 52 & $7 \%$ & 24 & 2355 & $1.27 \%$ & 45 & 31 & 1885 & 307 & 20 & 3 & 100 \\
\hline Lutjanus & 24 & 30 & $4 \%$ & 20 & 1968 & $1.06 \%$ & 66 & 68 & 1967 & 183 & 22 & 5 & 40 \\
\hline Selar & 7 & 30 & $4 \%$ & 2 & 7798 & $4.21 \%$ & 260 & 91 & 1350 & 494 & 20 & 4 & 100 \\
\hline Monotaxis & 14 & 17 & $2.29 \%$ & 17 & 675 & $0.36 \%$ & 40 & 23 & 2000 & 0 & 26 & 9 & 40 \\
\hline Cheilinus & 13 & 16 & $2.16 \%$ & 15 & 730 & $0.39 \%$ & 46 & 25 & 1906 & 272 & 24 & 6 & 75 \\
\hline NI (Non Identified) & 10 & 16 & $2.16 \%$ & 16 & 604 & $0.33 \%$ & 38 & 21 & 1813 & 512 & 25 & 6 & 40 \\
\hline Kyphosus & 6 & 15 & $2.02 \%$ & 13 & 830 & $0.45 \%$ & 55 & 35 & 2000 & 0 & 30 & 7 & 100 \\
\hline Lethrinus & 13 & 15 & $2.02 \%$ & 12 & 566 & $0.31 \%$ & 38 & 23 & 1933 & 258 & 27 & 12 & 40 \\
\hline Calotomus & 14 & 14 & $1.89 \%$ & 12 & 603 & $0.33 \%$ & 43 & 28 & 1893 & 289 & 25 & 4 & 100 \\
\hline Gnathodentex & 10 & 11 & $1.48 \%$ & 15 & 542 & $0.29 \%$ & 49 & 24 & 1955 & 151 & 22 & 3 & 100 \\
\hline Carangoides & 6 & 7 & $0.94 \%$ & 9 & 383 & $0.21 \%$ & 55 & 29 & 1857 & 244 & 41 & 23 & 100 \\
\hline Epibulus & 7 & 7 & $0.94 \%$ & 11 & 228 & $0.12 \%$ & 33 & 9 & 2000 & 0 & 26 & 8 & 100 \\
\hline Tylosurus & 4 & 7 & $0.94 \%$ & 3 & 478 & $0.26 \%$ & 68 & 35 & 714 & 567 & 67 & 36 & 100 \\
\hline Caranx & 4 & 6 & $0.81 \%$ & 5 & 333 & $0.18 \%$ & 55 & 33 & 2000 & 0 & 33 & 17 & 40 \\
\hline Crenimugil & 4 & 6 & $0.81 \%$ & 12 & 333 & $0.18 \%$ & 55 & 44 & 2000 & 0 & 22 & 2 & 40 \\
\hline Albula & 2 & 4 & $0.54 \%$ & 1 & 288 & $0.16 \%$ & 72 & 14 & 1750 & 289 & 65 & 19 & 100 \\
\hline Ctenochaetus & 3 & 3 & $0.40 \%$ & 8 & 94 & $0.05 \%$ & 31 & 26 & 1833 & 289 & 18 & 3 & 75 \\
\hline Pseudobalistes & 3 & 3 & $0.40 \%$ & 0 & 188 & $0.10 \%$ & 63 & 10 & 2000 & 0 & 63 & 10 & 100 \\
\hline Sphyraena & 3 & 3 & $0.40 \%$ & 6 & 275 & $0.15 \%$ & 92 & 76 & 1833 & 289 & 44 & 21 & 100 \\
\hline Chanos & 2 & 2 & $0.27 \%$ & 3 & 254 & $0.14 \%$ & 127 & 28 & 1250 & 1061 & 34 & 6 & 100 \\
\hline Heteropriacanth. & 2 & 2 & $0.27 \%$ & 5 & 159 & $0.09 \%$ & 80 & 86 & 2000 & 0 & 19 & 4 & 100 \\
\hline Liza & 2 & 2 & $0.27 \%$ & 8 & 85 & $0.05 \%$ & 42 & 3 & 1750 & 354 & 37 & 20 & 100 \\
\hline Priacanthus & 2 & 2 & $0.27 \%$ & 4 & 44 & $0.02 \%$ & 22 & 2 & 2000 & 0 & 17 & 1 & 100 \\
\hline Balistapus & 1 & 1 & $0.13 \%$ & 5 & 24 & $0.01 \%$ & 24 & & 1500 & & 17 & & 100 \\
\hline Cantherhines & 1 & 1 & $0.13 \%$ & 1 & 67 & $0.04 \%$ & 67 & & 2000 & & 36 & & 100 \\
\hline Coris & 1 & 1 & $0.13 \%$ & 8 & 21 & $0.01 \%$ & 21 & & 2000 & & 22 & & 100 \\
\hline All the survey ${ }^{\mathrm{a}}$ & 164 & $742^{g}$ & $100 \%^{h}$ & & 185054 & $100 \%$ & 249 & 106 & 1773 & 482 & 25 & 11 & \\
\hline
\end{tabular}

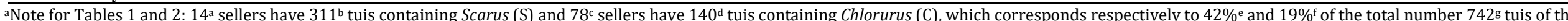

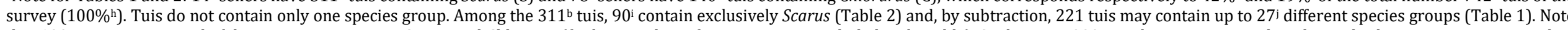

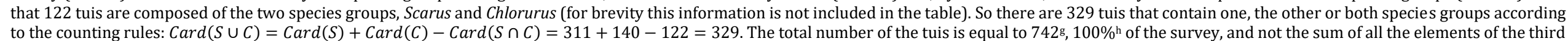
to the counting rules: $\operatorname{Card}(S \cup C)=\operatorname{Card}(S)+\operatorname{Card}(C)-\operatorname{Card}(S \cap C)=311+140-122=$
column. The same is true for the columns 3 and 4 in Table 1 and the number of sellers in Table 2 . 
1 In the sample, more than $90 \%$ of tuis containing Selar or Pelagic taxa are single-species tuis,

2 meaning that these species are rarely mixed. By contrast, the proportion of tuis containing only

3 Parupeneus, Epinephelus, Chlorurus or Mulloidichthys does not exceed 6\%, indicating that

4 these species groups are frequently mixed with others.

5 Table 2. Characteristics of the single species group tuis observed in the survey

\begin{tabular}{|c|c|c|c|c|c|c|c|c|c|c|c|}
\hline $\begin{array}{l}\text { Species group } j \\
\text { (by decreasing } \\
\text { number of tuis) }\end{array}$ & $\begin{array}{l}\text { Num. of } \\
\text { sellers }\end{array}$ & $\begin{array}{l}\text { Num. } \\
\text { of tuis }\end{array}$ & $\begin{array}{l}\text { \% of } \\
\text { single } \\
\text { species } \\
\text { group } \\
\text { tuis }\end{array}$ & $\begin{array}{l}\text { Num. of } \\
\text { tuis } \\
\text { Single/Al } \\
1 \text { tuis (\%) }\end{array}$ & $\begin{array}{l}\% \\
\text { Length } \\
\text { of Single } \\
\text { Species } \\
\text { group } \\
\text { tuis/ all } \\
\text { tuis }\end{array}$ & $\begin{array}{l}\text { Average } \\
\text { Length } \\
\text { of } \\
\text { species } \\
\text { group } j \\
\text { in single- } \\
\text { species } \\
\text { group } \\
\text { tuis }(\mathrm{cm})\end{array}$ & $\begin{array}{l}\text { SD } \\
\text { Length } \\
\text { of } \\
\text { species } \\
\text { group } j \\
\text { in } \\
\text { single- } \\
\text { species } \\
\text { group } \\
\text { tuis } \\
(\mathrm{cm})\end{array}$ & $\begin{array}{l}\text { Average } \\
\text { Price of } \\
\text { a tui } \\
(\mathrm{CFP})\end{array}$ & $\begin{array}{l}\text { SD Price } \\
\text { of a tui } \\
\text { (CFP) }\end{array}$ & $\begin{array}{l}\text { Average } \\
\text { Price of } \\
\text { species } \\
\text { group } j \\
\text { (CFP/10 } \\
\text { cm) }\end{array}$ & $\begin{array}{l}\text { SD } \\
\text { Price of } \\
\text { species } \\
\text { group } j \\
(\mathrm{CFP} / 1 \\
\mathbf{0} \mathrm{cm})\end{array}$ \\
\hline Scarus & 55 & $90^{i}$ & $25 \%$ & $29 \%$ & $41 \%$ & 262 & 82 & 1961 & 154 & 84 & 34 \\
\hline Chlorurus & 5 & 6 & $2 \%$ & $4 \%$ & $16 \%$ & 264 & 108 & 1833 & 408 & 107 & 119 \\
\hline Parupeneus & 4 & 5 & $1 \%$ & $4 \%$ & $10 \%$ & 224 & 91 & 2000 & 0 & 109 & 64 \\
\hline Myripristis & 18 & 43 & $12 \%$ & $37 \%$ & $57 \%$ & 252 & 106 & 1977 & 152 & 107 & 88 \\
\hline Mulloidichthys & 6 & 7 & $2 \%$ & $6 \%$ & $17 \%$ & 293 & 90 & 1857 & 378 & 69 & 27 \\
\hline Siganus & 19 & 34 & $9 \%$ & $33 \%$ & $52 \%$ & 239 & 91 & 1971 & 171 & 160 & 280 \\
\hline Pelagic & 19 & 85 & $24 \%$ & $94 \%$ & $91 \%$ & 169 & 69 & 850 & 533 & 62 & 62 \\
\hline Naso & 14 & 30 & $8 \%$ & $35 \%$ & $53 \%$ & 120 & 86 & 1933 & 254 & 233 & 121 \\
\hline Epinephelus & 2 & 3 & $1 \%$ & $4 \%$ & $17 \%$ & 506 & 233 & 2000 & 0 & 49 & 30 \\
\hline Acanthurus & 4 & 7 & $2 \%$ & $12 \%$ & $34 \%$ & 309 & 28 & 2000 & 0 & 65 & 5 \\
\hline Selar & 5 & 27 & $7 \%$ & $90 \%$ & $94 \%$ & 271 & 90 & 1333 & 460 & 76 & 120 \\
\hline $\begin{array}{l}\text { All the single } \\
\text { species groups } \\
\text { of the survey }\end{array}$ & 118 & 361 & $100 \%$ & $49 \%$ & $42.12 \%$ & 216 & 107 & 1620 & 594 & & \\
\hline
\end{tabular}

7 The large number of single-species tuis and their broad taxonomic representation allowed

8 calculation of average prices of a number of individual species groups. Table 2 provides

9 statistics regarding the characteristics of these tuis, including average and standard deviation of

10 prices per species group for the 11 species groups observed in the survey among the 14 most

11 frequent.

12 Tables 1 and 2 highlight the strong heterogeneity of tuis in terms of length, price and species

13 group composition. Using a benchmark length of $10 \mathrm{~cm}$ to calculate species-group prices, we

14 observe that the price of the 11 most frequent species groups varies considerably: the species

15 group with the lowest average price, Epinephelus $(49 \mathrm{CFP} / 10 \mathrm{~cm}$ ) is more than four times less

16 expensive than the species group with the highest price (Naso, $233 \mathrm{CFP} / 10 \mathrm{~cm}$ ). 
Not unexpectedly, prices of single-species group tuis differ from one species group to another.

But strikingly, they also differ within each species group, both among sellers and among tuis for the same quantity (length) of fish. Measured by the standard deviation (SD in Tables 1 and 2), these deviations range from $34 \mathrm{CFP}$ for an average price of 84 CFP for Scarus to $119 \mathrm{CFP}$ for an average price of 107 CFP for Chlorurus, which are the two most frequently encountered species groups in the sample. For Chlorurus and two other species groups, Siganus and Selar (making up a total of $17 \%$ of single species group tuis), the deviations are even greater than average prices: by $11 \%, 175 \%$ and $156 \%$ respectively. Such price disparities for the same species group between tuis and sellers may relate to the length of the individual fish (consumers may prefer fish pieces of shorter or longer lengths depending on the species groups) and thus to the number of pieces included in the tuis.

Overall, however, the observed price disparities imply the existence of a wide variety of quality attributes of the fish being sold. These attributes may relate to the tuis, their composition in terms of variety of species groups and length of fish offered, but also to the sellers, the fishing techniques used to catch the fish and other determinants of their quality, such as fishing location. Indeed, in addition to the composition and price of tuis, the roadside surveys also collected information regarding the sellers, particularly where and how the fish composing the tuis had been caught, which may directly affect their quality, and hence the price. Table 3 presents the qualitative variables measuring these quality attributes.

Among quality attributes of fish, freshness is a key factor. Local buyers have a keen sense of how long a fish has been out of the water based on the color of the gills, opacity of the eyes, texture of the skin, flesh and fins, and smell of the entrails, with the key indicators of freshness differing across species groups. Many of these factors, however, are subtle and difficult to generalize. In order to control for these factors involving freshness, roadside sellers were asked 
had low variability and a skewed distribution. $83.98 \%$ of fishers declared departure time was

43 between $6 \mathrm{pm}$ and midnight, which corresponds to $85.21 \%$ of the quantity of fish sold. Most

44 fish were thus taken at night and sold the next morning to ensure freshness at the time of sale.

45 In addition, the low variability of the time when fish were caught is closely linked to many

46 other factors in our empirical model such as "Habitat" and "Boat". Because of these problems

47 of low variability and collinearity with other factors, we do not introduce the time variable in

48 our estimation.

Table 3. Qualitative attributes characterizing the sellers and fish sold

\begin{tabular}{|c|c|c|c|c|c|}
\hline \multirow{2}{*}{\multicolumn{2}{|c|}{ Variable }} & \multicolumn{2}{|c|}{164 SELLERS } & \multicolumn{2}{|c|}{742 TUIS } \\
\hline & & $\mathbf{n}$ & $\%$ & $\mathbf{n}$ & $\%$ \\
\hline \multirow[t]{4}{*}{ HABITAT } & LAGOON & 119 & $73 \%$ & 561 & $76 \%$ \\
\hline & REEF & 28 & $17 \%$ & 104 & $14 \%$ \\
\hline & PASS & 9 & $5 \%$ & 29 & $4 \%$ \\
\hline & OPEN OCEAN & 8 & $5 \%$ & 48 & $6 \%$ \\
\hline \multirow[t]{2}{*}{ CREW } & FISH WITH CREW & 101 & $62 \%$ & 525 & $71 \%$ \\
\hline & FISH ALONE & 63 & $38 \%$ & 217 & $29 \%$ \\
\hline \multirow{9}{*}{$\begin{array}{l}\text { FISHING } \\
\text { GEAR }\end{array}$} & SPEARGUN & 136 & $83 \%$ & 618 & $83 \%$ \\
\hline & - with un-motorized boat & 72 & $44 \%$ & 264 & $36 \%$ \\
\hline & - with motorized boat & 38 & $23 \%$ & 244 & $33 \%$ \\
\hline & - without boat & 26 & $16 \%$ & 110 & $15 \%$ \\
\hline & POTI MARARA Fishing & 11 & $7 \%$ & 72 & $10 \%$ \\
\hline & LINE & 10 & $6 \%$ & 26 & $4 \%$ \\
\hline & $\bullet$ with motorized boat & 9 & $5 \%$ & 24 & $3 \%$ \\
\hline & NET & 7 & $4 \%$ & 26 & $4 \%$ \\
\hline & - with un-motorized boat & 4 & $2 \%$ & 18 & $2 \%$ \\
\hline \multirow{2}{*}{ BOAT } & WITH MOTOR & 69 & $42 \%$ & 379 & $51 \%$ \\
\hline & WITHOUT MOTOR & 67 & $41 \%$ & 246 & $33 \%$ \\
\hline \multirow[t]{6}{*}{ BOAT TYPE } & VAA & 80 & $49 \%$ & 334 & $45 \%$ \\
\hline & - un-motorized & 67 & $41 \%$ & 246 & $33 \%$ \\
\hline & - low power $(\leq 40 \mathrm{HP})$ motorized & 13 & $8 \%$ & 88 & $12 \%$ \\
\hline & POTI MARARA & 56 & $34 \%$ & 291 & $39 \%$ \\
\hline & - high power (>4O HP) motorized & 53 & $32 \%$ & 286 & $39 \%$ \\
\hline & NONE (without boat) & 28 & $17 \%$ & 117 & $16 \%$ \\
\hline
\end{tabular}

51 Fish offered on the tuis came from several different reef habitats. However, the vast majority

52 of landings originated from the lagoon or coral reef areas: $76 \%$ of tuis (offered by $73 \%$ of

53 sellers) came from the lagoon, and $14 \%$ of tuis (offered by $17 \%$ of sellers) came from reef areas

54 and the remaining $10 \%$ from the pass and open ocean. A total of $38 \%$ of sellers had been fishing

55 alone, and were offering $29 \%$ of tuis. A large majority of the fish offered had been caught with

56 an average crew of 2 people, but some crews were as large as 7 . The two most widely used

57 fishing methods were speargun and polyvalent fishing methods including harpoon and line 
fishing techniques from motorboats called poti marara, often with powerful motors. Spearguns ${ }^{6}$

had been used by 136 sellers $(82.93 \%)$ to land $83 \%$ of the fish offered on tuis; and poti marara

fishing had been used by $7 \%$ of the sellers to land $10 \%$ of the tuis. These are both fairly selective

fishing methods. Sellers (80 out of the 164) also used vaas (outrigger canoes), without motors

or with very small motors, to catch the fish on offer in $45 \%$ of the tuis. In addition, a significant part of the fish sold was caught without a boat: about $16 \%$ of tuis consisted of fish caught while swimming from shore by $17 \%$ of the sellers. Finally, the survey showed that sellers had only rarely used multiple techniques to catch the fish offered on their tuis.

Additional information regarding the fishing trips was obtained during the surveys of sellers.

Table 4 summarizes quantitative attributes of fish catches. A total of $42 \%$ of sellers used motor boats with an average engine power of 39 HP. Trip length varied, with an average duration of

6 hours. This trip length did not change when sellers used more powerful boats, although it did

vary across fishing locations (with shorter trips when fishing in the lagoon and longer (1-2 hour)

71 trips when going to the reef and beyond). Only 28 sellers (17\%) retained a fraction of their catch before composing their tuis. Their retained catch averaged about one fourth of their total catch

73 (22\%), with a maximum value of $62 \%$.

Table 4. Quantitative attributes characterizing the sellers

\begin{tabular}{llcccc}
\hline Variable & Definition & $\begin{array}{c}\text { \% of } \\
\text { non- } \\
\text { zero }\end{array}$ & Average & (SD) & Max \\
\hline HP & Engine power (HP) & $42 \%$ & 39 & $(21)$ & 125 \\
CREW & Number of crew & $61.59 \%$ & 1.87 & $(1.25)$ & 7 \\
HOUR FISH & Hours fishing & $100 \%$ & 6 & $(3)$ & 17 \\
FRAQ KEPT & Fraction of catch kept for family and friends (not & $17 \%$ & $22 \%$ & $(13)$ & $62 \%$ \\
& sold) & & & & \\
\hline
\end{tabular}

75 The empirical observations of tui sales derived from the roadside survey summarized in Tables

$76 \quad 1-4$ highlight a wide heterogeneity in the characteristics of tuis. A modelling approach is thus

77 needed to address these different sources of heterogeneity in order to assess the extent to which

\footnotetext{
${ }^{6}$ A skilled spearfisher will shoot fish in particular spots to maintain the fish's aesthetics.
} 
changes in the quantities (lengths) of fish of different species groups offered on tuis are likely to affect their price, all else being equal.

\section{Hedonic Modeling Approach}

Hedonic modeling approaches are beginning to be applied in seafood studies as for health goods (Jensen et Morrisey 1990), real estate (Farber 1998), computers (Karamti, s. d.), and agricultural (Roka et Palmquist 1997) or environmental goods (Freeman, Herriges, et Kling 2014). This development has been driven by new evaluation questions, relating to the identification of attributes impacting the quality of seafood, as well as their associated monetary value (Carroll, Anderson, et Martínez-Garmendia 2001; Larkin et Sylvia 1999; McConnell et Strand 2000; Shimose, Kanaiwa, et Nanami 2019). The approach builds on the observation that on a market, the price of a good is dependent on several attributes that are intrinsic or extrinsic to it, and that measure the level of good quality in its different dimensions. Applications of the approach have thus also relied on the increasing availability of adequate data sets of good quality.

In the case of the Moorea market for fish, since sales are based on the catch of the day and a direct interaction between fishers and fish consumers, demand and supply adjustments can be considered to be very short-term. This is a small-scale subsistence fishery and a closely connected island market of a basic consumption good. Hence it is not surprising to assume in this study that sellers as well as consumers have all and the same information at the moment of the sale ${ }^{7}$. However, demand is expected to be more sensitive to market changes, while supply is constrained by environmental conditions determining access to fishing grounds as well as the productivity of fishing effort, which is in turn related to fish abundance. Given this, the

\footnotetext{
${ }^{7}$ Some authors introduce more adequate econometric methods to deal with asymmetric information with seller overestimating and consumer underestimating price (Kumbhakar et Parmeter 2010; Bonanno et al. 2019)).
} 
willingness to pay to dispose of an additional quantity of fish of a given species group is

101 expected to be equivalent to observed marginal variations in the (hedonic) price of tuis.

102 Contrary to demand, in the context of Moorea reef fisheries, the supply of fish is considered not

103 flexible enough to follow market variations so that the (marginal) cost of fishing an additional

104 quantity could be equivalent to the variations of (hedonic) prices of tuis. Fishers who sell part

105 of their catch are aware of this and are compelled to compose their tuis and set the tui price

106 taking into account the preferences of local consumers.

107 Following Rosen (1974), we estimate the implicit price of individual species groups of fish

108 encountered on tuis using the two-step hedonic price approach. First we estimate the hedonic

109 price model of tuis and, second, the implicit price model of the fourteen most abundant species

110 groups in our sample. For the purpose of our analysis, we consider a set of intrinsic and extrinsic

111 attributes that have been shown to determine seafood quality in previous studies (Hammarlund

112 2015; Larkin et Sylvia 1999; McConnell et Strand 2000).

113 We also considered factors that might affect the quality of the fish of each species group.

114 Ciguatera fish poisoning is an important health and safety issue in coral reef fisheries, including

115 in Moorea (Morin et al. 2016). Caused by a toxin that is produced by dinoflagellates and

116 contained in fish tissues, the risk of contamination varies greatly among different taxa of fish.

117 We thus included a qualitative score capturing the absence of risk associated with Ciguatera for

118 a species group $j$, noted $W^{j}$, varying from 40 (high risk of Ciguatera) to 100 (no Ciguatera risk)

119 for each of the 37 species groups (Table 1$)^{8}$. The length of the $j^{\text {th }}$ species group was weighted

120 by its relative absence of Ciguatera risk $W_{i t}^{j}=L_{i t}^{j} W^{j} / \sum_{l=1}^{J} L_{i t}^{l} W^{l}$ combined with the

121 importance of its length $L_{i t}^{j}$ in the tui $t$ of the seller $i\left(L_{i t}^{l}\right.$ is the length in $\mathrm{cm}$ of each $l^{\text {th }}$ species

\footnotetext{
${ }^{8}$ The scores were established based on expert knowledge of researchers from CRIOBE (Centre de Recherches Insulaires et Observatoire de l'Environnement, www.criobe.pf). Although ciguatera risk can vary spatially somewhat around the island, for our analyses we applied the same risk factor to a species regardless of where it was caught because finer-scale risk patterns have not been quantified for Moorea.
} 
group present in this tui). The hedonic price of a tui $P_{i t}$ is assumed to depend on the aggregate

123 length of fish $L P_{i t}=n_{i t} \sum_{j=1}^{37} L_{i t}^{j} \omega_{i t}^{j}$ of all species groups $j=\left\{1, \ldots, n_{i t}\right\}$ composing the tui $t$

124 of the seller $i$, weighted by its relative Ciguatera absence score $\omega_{i t}^{j}=W^{j} / \sum_{l=1}^{n_{i t}} W^{l}$ depending

125 on whether the species group is or is not present in the tui.

126 According to different studies of seafood products (Aubanel 1993; Leenhardt et Moussa 2012;

127 McConnell et Strand 2000; Moussa 2010; Vignes et Etienne 2011), the quality of fish products

128 strongly depends on the fishing techniques used to catch the fish. These are considered by both

129 sellers and buyers of fish as indicators of the quality of seafood. In the context of Moorea, as

130 shown in Table 3, fish are largely caught with a speargun. This technique is likely to be

131 perceived as producing high quality fish as it is selective and preserves the fish flesh (Nielsen,

132 Hyldig, et Larsen 2002). The location of the catch, whether from the lagoon or the reef, can

133 also be an additional quality indicator. Tables 3 and 4 summarize the available data regarding

134 these quality attributes of the fish sold.

135 Using these attributes (represented by the matrix $Z$ ), we estimate the following log-quadratic

136 specification of the hedonic tui price equation:

$$
\ln (P)=\alpha_{0}+\alpha_{m}+Z \theta+\sum_{j} \rho_{j} I^{j}+\beta_{1} L P+\beta_{2} L P^{2}+\varepsilon
$$

138 This specification enables measuring $\rho_{j}$, the equivalent of a lump sum payment incorporated

139 in the price of tui containing the individual species group $j$, provided it is present in the tui

$140 \quad\left(I_{i t}^{j}=1\right.$ if $L_{i t}^{j}>0 ; 0$ otherwise $)$ regardless of the quantity available. Fixed effects are also

141 introduced when estimating the model in order to account for the potential existence of temporal

142 trends $\alpha_{m}$, or other sources of unobservable heterogeneity between tuis or sellers 9 .

\footnotetext{
${ }^{9}$ Other fixed effects parameters were tested during the estimation process, in order to take into account disparities between tuis of each fisher, including the location of sales considered at different scales, but these proved not statistically significant.
} 
143 The Rosen two-step evaluation procedure consists of deriving the purchaser willingness to pay

$144 \widehat{P W P}_{i t}^{j}$ for a marginal increase in length of each species group $j$ from the derivative of the tui's

145 hedonic price, as follows:

$$
\widehat{P W P}_{i t}^{j}=\widehat{P}_{i t} \omega_{i t}^{j}\left(\widehat{\beta}_{1}+2 \widehat{\beta}_{2} L P_{i t}\right)
$$

147 Following standard recommendations of Heckman, Matzkin, et Nesheim (2010) and the 148 pioneering studies of Griliches (2013), Freeman, Herriges, et Kling (2014) and Mäler et Vincent 149 (2005), three methods are used to identify such demand functions for each species group $j$ in 150 the Rosen two-stage model.

151 First, the estimation relies on flexible non-linear specifications with changes in the functional 152 form of the hedonic tui price and the demand functions of each species group. The hedonic 153 price of the tui is assumed to be a log-quadratic function of its aggregated length (Equation 1) 154 while the demand function of the $j^{\text {th }}$ species group is a translogarithmic function (Berndt et 155 Christensen 1973) of the length of all the species group present in the tui (Equation 3):

$$
\begin{aligned}
\ln \left(\widehat{P W P}^{j}\right) & =\alpha_{0}^{j}+\alpha_{m}^{j}+Z \theta^{j}+X \delta^{j}+\sum_{k \neq j} \rho_{k}^{j} I^{k}+\sum_{l=1}^{J} \beta_{l}^{j} \ln \left(L^{l}\right)+ \\
& +\sum_{l=1}^{J} \beta_{k l}^{j} \ln \left(L^{j}\right) \ln \left(L^{l}\right)+\mu^{j}
\end{aligned}
$$

where $X$ is the matrix summarizing the available demand factors (see below).

Second, the species group demand function (Equation 3) is estimated in the second-stage with a stratified sample database containing the species group under consideration while the firststage model is estimated using the entire data set. The third column of Table 1 shows that all species groups are not present in all tuis. The first fourteen species groups in the table occurred most frequently in this market, such as Scarus which is present in $42 \%$ of the tuis (see next section). Third, identification is based on geographical demand factors (named $X$ in Equation (3) and described in Table 5) characterizing the demand for fish in the different locations based on 
167 where each tui was sold. We distinguish the five municipalities of Moorea using a municipality

168 fixed effect ${ }^{10}$ and a set of instrumental variables to measure purchasing power in each

169 municipality, such as unemployment rate, population density and population change (Bellwood,

170 Hoey, et Hughes 2012). Indeed, these instrumental variables show that the five municipalities

171 differ in some characteristics, which may directly affect the local demand for fish ${ }^{11}$.

172 Table 5. Geographical demand factors

\begin{tabular}{|c|c|c|c|c|c|c|c|c|c|c|}
\hline \multirow{2}{*}{ Municipal. } & \multicolumn{2}{|c|}{ Sellers } & \multicolumn{2}{|c|}{ Tuis } & \multirow{2}{*}{$\begin{array}{l}\text { POP } \\
\text { Populat } \\
\text { ion in } \\
2012\end{array}$} & \multirow[b]{2}{*}{$\begin{array}{l}\text { POPVAR } \\
\text { Population } \\
\text { growth } \\
\text { between } \\
1977 \text { and } \\
2012 \\
\end{array}$} & \multirow{2}{*}{$\begin{array}{l}\text { SURFACE } \\
\text { Area in } \mathrm{km}^{2}\end{array}$} & \multirow{2}{*}{$\begin{array}{l}\text { DENSITY } \\
\text { Population } \\
\text { density per } \\
\mathrm{km}^{2}\end{array}$} & \multirow[b]{2}{*}{$\begin{array}{l}\text { POIDEMOG } \\
\% \text { of } \\
\text { municipality in } \\
\text { total population } \\
2017\end{array}$} & \multirow{2}{*}{$\begin{array}{l}\text { UNEMPL } \\
\text { Unemploym } \\
\text { ent rate in } \\
2012\end{array}$} \\
\hline & $\mathrm{n}$ & $(\%)$ & $\mathrm{n}$ & $(\%)$ & & & & & & \\
\hline Afareaitu & 229 & $(30.86 \%)$ & 69 & $(42.07 \%)$ & 3455 & 277.50 & 23.80 & 145.20 & 21.04 & 33.80 \\
\hline Рaopao & 305 & $(41.11 \%)$ & 40 & $(24.39 \%)$ & 4580 & 271.00 & 30.00 & 152.70 & 26.56 & 15.60 \\
\hline Haapiti & 106 & $(14.29 \%)$ & 32 & $(19.51 \%)$ & 4062 & 352.30 & 38.80 & 104.70 & 24.36 & 21.60 \\
\hline Papetoai & 80 & $(10.78 \%)$ & 16 & $(9.76 \%)$ & 2318 & 339.90 & 25.10 & 92.40 & 13.34 & 26.80 \\
\hline Teavaro & 22 & $(2.96 \%)$ & 7 & $(4.27 \%)$ & 2484 & 311.30 & 15.80 & 157.20 & 14.70 & 21.80 \\
\hline TOTAL & 742 & (100\%) & 164 & $(100 \%)$ & & & & & & \\
\hline
\end{tabular}

173 Other instruments are also used to account for the impact of the fish supply differentiation

174 operated by sellers in this market. Three instruments are calculated from the database (Table

175 6), which correspond to the number of tuis (NTUIS) and the total number of species groups

176 (NSPECV) offered by each seller, as well as the total number of species groups in each tui

177 (NSPECT). The two first instruments vary in one dimension, between fishers, and the third in

178 two dimensions, between fishers and tuis. Indeed, $50 \%$ of fishers offer more than 3 tuis (some

179 of them up to 23 tuis) while the number of species groups varies from 5 to 14 between sellers

180 and from 2 to 9 among the tuis of individual sellers.

181 Table 6. Definition and descriptive statistics of supply differentiation instruments

\begin{tabular}{llrccc}
\hline Variable & Signification & Mean & $($ SD) & Median & Max \\
\hline NTUIS & Number of tuis of each seller & 4.52 & $(3.60)$ & 3 & 23 \\
NSPECV & Number of species groups of each seller & 5.29 & $(3.44)$ & 5 & 14 \\
NSPECT & Number of species groups in each tui of each seller & 2.08 & $(1.41)$ & 2 & 9 \\
\hline
\end{tabular}

\footnotetext{
${ }^{10}$ Each municipality is represented by a dummy variable. One of the five municipalities is excluded in the estimation as a reference modality. This statistical precaution is respected for all the other binary variables.

${ }^{11}$ Equations 1 and 3 are estimated with Stata16 software. All available factors are introduced using a stepwise estimation approach with backward selection, only the variables with statistically significant parameters at the $90 \%$ confidence level are retained in the final model.
} 
182 As for the hedonic price of tuis, species group pricing strategies have a quantitative dimension

183 in the demand function (i.e., the price and length of fish offered), as well as a qualitative

184 dimension: sellers can combine species groups $j$ in variable proportions. To capture this, the

185 binary indicator $I_{i t}^{k}=(1,0)$ is included in the model, specifying that the $k^{\text {th }}$ species group

$186(k=1, \ldots, J ; k \neq j)$ is present in the tui with the $j^{\text {th }}$ species group, in addition to its length $L_{i t}^{k}$.

187 The final step in Rosen's model is a monetary evaluation of the additional length (quantity) $\Delta L$

188 of individual species group $j$ in the tui using the estimated demand function. This amount is

189 equivalent to the sum of the purchaser's willingness to pay for this additional quantity using the

190 estimated Equation 3. Represented by $\boldsymbol{p}^{j}\left(\boldsymbol{L}^{*}\right)$, this is the price in CFP of an additional length

$191 \Delta L$ taken to be $10 \mathrm{~cm}$, or one extra piece of fish, as follows:

$$
p^{j}\left(L^{*}\right)=\int_{L^{*}}^{L^{*}+\Delta L} \widehat{P W P}^{j}(x) d x
$$

193 This price is not a fixed amount but varies according to the length of the tui because of the

194 flexibility of the estimated demand function (Equation 3). We calculate this price for a fixed

195 reference length of each species group $j, L^{*}=100 \mathrm{~cm}$, which is the per tui median length

196 encountered for the fourteen most frequent species groups in this market.

\section{Results}

198 Applying least square estimation of Equation 1 and the backward stepwise selection procedure

199 of significant variables, we find that several factors have decisive effects on tui prices that seem

200 consistent with the reality of the market (Table 7 and commentary below). The overall level of 201 reliability of the results is relatively high: the empirical model offers significant explanatory 202 power of tui price variations, with an overall coefficient of determination between $64 \%$ and $20376 \%$, and its level of reliability exceeds $99.9 \%$ based on the Fisher test. 
204 However, there is reason to doubt the exogeneity of two of the explanatory variables. These 205 relate to the fraction of the catch retained by the seller for his personal use (KEPT_UN, a binary 206 variable which identifies sellers who keep part of their catch for themselves, and FRAQ_KEPT, 207 the share-in percentage of this fraction). It is possible that this fraction is kept because of the 208 value of the fish and the species group landed. These variables therefore relate to decisions that 209 are specific to sellers (to retain part of the catch, and how much), and may not be independent 210 of the price of the tuis offered for sale. Carrying out the Hausman test (using its Nakamura and 211 Nakamura version) confirms this. To correct the ensuing endogeneity bias, we use a 2SLS 212 method retaining four instrumental variables in addition to the significant explanatory variables. 213 These instruments provide information on the standard of living in the geographical areas where 214 sellers sell the tuis (usually close to their home), measured via levels of unemployment as well 215 as the demographic weight of the municipality (respectively UNEMPL and POIDEMOG in 216 Table 5) and variables capturing the diversity of catches measured by the number of species 217 groups available from each seller (Table 6) and whether or not the seller is the fisher who caught 218 the fish being sold (79.88\% of sellers are the fisher). The estimated auxiliary equation using a 219 2SLS method shows that most of these instruments have significant impact on the endogenous 220 factor FRAQ-KEPT. In addition, performing the Sargan over-identification test confirms the 221 validity of these instruments ${ }^{12}$.

222 Results from the estimation of Equation 3 with OLS and 2SLS are presented in Table 7. Given 223 the endogeneity problem mentioned above, only the 2SLS estimation is considered hereafter. 224 The Price Index column of the table gives the value of the tui price index for each category of 225 the binary variables and the marginal/elasticity effect for the quantitative explanatory variables.

226 After correcting the endogeneity bias, we note that the price of tuis is $175 \%$ higher on average 227 for sellers who retain a share of their catch for their consumption. However, this price drops as

\footnotetext{
${ }^{12}$ The significance level of this test is $24.30 \%$, for the null hypothesis not to be rejected.
} 
the retained share increases, which may be related to the fact that the most highly priced fish are those that are retained by the sellers first.

230 The price of a tui is an increasing function of its length. This function is quadratic: the price

231 increase is steeper for longer tuis. The price elasticity is $7.16 \%$ for a tui of average length (252

$232 \mathrm{~cm})$, but varies according to the different factors introduced in the model.

233 Our results indicate that of the 37 species groups that compose tuis, the presence of four ${ }^{13}$ has

234 a fixed effect on tui prices. Based on parameter values, the price of a tui is lower if it contains

235 Chanos, Mulloidichthys, Pelagic taxa and Tylosurus; the tui price index decreases on average

236 to $59 \%, 92 \%, 55 \%$ and $54 \%$ respectively in these cases (last column in Table 7). Two of these

237 species groups (Chanos and Tylosurus) are rare in this market, representing only $0.4 \%$ of the

238 total length of all of the 37 species groups (Table 1).

239 The results also reveal the existence of monthly fixed effects with lower prices of tuis in the

240 months of February, July, and the last four months of the year. As reported by Graddy (2006),

241 these seasonal variations may highlight a strong dependency of the fresh seafood market on the

242 suitability of sea conditions for fishing as well as temporal differences in the amount of time

243 available for fishers to participate in the fishery (relative to other activities).

244 In addition, fishers who sell fish they caught on their own or with smaller crew have tuis with

245 Table 7. Estimated hedonic price function of tuis (Equation 3): 2SLS method vs OLS

\begin{tabular}{|c|c|c|c|c|c|c|c|c|}
\hline & & \multicolumn{2}{|c|}{ Statistics } & \multicolumn{2}{|c|}{ OLS } & \multicolumn{3}{|c|}{2 SLS } \\
\hline & VARIABLES & Mean & SD & $\beta$ : Param. & ( $p$ value $)$ & $\beta$ : Param. & (p value) & $\begin{array}{c}\text { Price Index } \\
e^{\beta} \text { or Elasticity* }\end{array}$ \\
\hline \multirow{3}{*}{ Length } & $\mathrm{L}$ & 249.4 & 106.0 & & & & & \\
\hline & LP & 252.6 & 109.9 & N.S. & & N.S. $^{14}$ & & \\
\hline & $\mathbf{L P}^{2}$ & 75,877 & 65,450 & $4.32 \mathrm{e}-07$ & $(0.000)$ & $4.83 \mathrm{e}-07$ & $(0.004)$ & $7.16 \% *$ \\
\hline \multirow{2}{*}{$\begin{array}{l}\text { Species } \\
\text { group }\end{array}$} & $\begin{array}{l}\text { Chanos } \\
(1 \text { vs. } 0)\end{array}$ & 0.00270 & 0.0519 & -0.515 & $(0.000)$ & -0.535 & $(0.005)$ & $59 \%$ \\
\hline & $\begin{array}{l}\text { Monotaxis } \\
(1 \text { vs. } 0)\end{array}$ & 0.0229 & 0.150 & 0.0930 & $(0.077)$ & N.S.. & & \\
\hline
\end{tabular}

${ }^{13}$ There is a fifth species group (Monotaxis) present in $2.29 \%$ of our sample, which seems to be the only species increasing the value of tuis (it increases prices by 106\%) but the estimated parameter is not statistically reliable after correcting for endogeneity.

${ }^{14} p$ value of bilateral Student test exceeding $10 \%$. 


\begin{tabular}{|c|c|c|c|c|c|c|c|c|}
\hline & $\begin{array}{l}\text { Mulloidichthys } \\
(1 \text { vs. } 0)\end{array}$ & 0.146 & 0.353 & -0.0517 & $(0.022)$ & -0.0840 & $(0.003)$ & $92 \%$ \\
\hline & \begin{tabular}{|l|} 
Pelagic \\
$(1$ vs. 0$)$ \\
\end{tabular} & 0.121 & 0.327 & -0.594 & $(0.000)$ & -0.597 & $(0.000)$ & $55 \%$ \\
\hline & \begin{tabular}{|l|} 
Tylosurus \\
$(1$ vs. 0$)$
\end{tabular} & 0.00943 & 0.0967 & -0.650 & $(0.000)$ & -0.622 & $(0.000)$ & $54 \%$ \\
\hline \multirow{6}{*}{ Trend } & \begin{tabular}{|l|} 
February \\
$(1$ vs. 0$)$
\end{tabular} & 0.0741 & 0.262 & -0.0993 & $(0.002)$ & -0.224 & $(0.000)$ & $80 \%$ \\
\hline & \begin{tabular}{|l} 
July \\
(1 vs. 0) \\
\end{tabular} & 0.164 & 0.371 & -0.187 & $(0.000)$ & -0.166 & $(0.000)$ & $85 \%$ \\
\hline & \begin{tabular}{|l} 
September \\
(1 vs. 0) \\
\end{tabular} & 0.131 & 0.337 & -0.120 & $(0.000)$ & -0.194 & $(0.000)$ & $82 \%$ \\
\hline & $\begin{array}{l}\text { October } \\
(1 \text { vs. } 0) \\
\end{array}$ & 0.0606 & 0.239 & -0.0691 & $(0.052)$ & -0.170 & $(0.000)$ & $84 \%$ \\
\hline & \begin{tabular}{|l|} 
November \\
$(1$ vs. 0$)$ \\
\end{tabular} & 0.0916 & 0.289 & -0.0634 & $(0.032)$ & -0.154 & $(0.000)$ & $86 \%$ \\
\hline & \begin{tabular}{|l}
$\begin{array}{l}\text { December } \\
(1 \text { vs. } 0)\end{array}$ \\
\end{tabular} & 0.0566 & 0.231 & -0.277 & $(0.000)$ & -0.337 & $(0.000)$ & $71 \%$ \\
\hline \multirow{4}{*}{$\begin{array}{c}\text { Crew and } \\
\text { hour } \\
\text { fishing. } \\
x 0=\mathbf{2 . 6 2}\end{array}$} & $\begin{array}{l}\text { ALONE } \\
(1 \text { vs. } 0)\end{array}$ & 0.292 & 0.455 & 0.212 & $(0.000)$ & 0.167 & $(0.000)$ & $118 \%$ \\
\hline & CREW & 1.511 & 1.563 & 0.237 & $(0.000)$ & 0.204 & $(0.000)$ & \\
\hline & \begin{tabular}{|l} 
CREW $^{2}$ \\
\end{tabular} & 4.721 & 9.209 & -0.0451 & $(0.000)$ & -0.0399 & $(0.000)$ & \\
\hline & HOUR_FISH & 5.757 & 2.948 & -0.00560 & $(0.043)$ & -0.00953 & $(0.007)$ & \\
\hline \multirow{2}{*}{ Gear } & $\begin{array}{l}\text { LINE } \\
(1 \text { vs. } 0) \\
\end{array}$ & 0.0499 & 0.218 & 0.124 & $(0.003)$ & 0.137 & $(0.011)$ & $115 \%$ \\
\hline & $\begin{array}{l}\text { SPEARGUN } \\
(1 \text { vs. } 0)\end{array}$ & 0.833 & 0.373 & 0.102 & $(0.001)$ & N.S.. & & \\
\hline \multirow{5}{*}{$\begin{array}{c}\text { Boat and } \\
\text { HP }\end{array}$} & \begin{tabular}{|l} 
BOAT_POTI \\
$(1$ vs. 0$)$
\end{tabular} & 0.392 & 0.489 & 0.350 & $(0.002)$ & 0.354 & $(0.013)$ & $142 \%$ \\
\hline & $\begin{array}{l}\text { MOTOR } \\
(1 \text { vs. } 0) \\
\end{array}$ & 0.511 & 0.500 & 0.225 & $(0.000)$ & 0.122 & $(0.054)$ & $113 \%$ \\
\hline & \begin{tabular}{|l|} 
POWER >40 HP \\
$(1$ vs. 0$)$
\end{tabular} & 0.385 & 0.487 & 0.494 & $(0.000)$ & 0.584 & $(0.000)$ & $179 \%$ \\
\hline & $\mathrm{HP}$ & 18.89 & 23.78 & -0.0392 & $(0.000)$ & -0.0403 & $(0.000)$ & \\
\hline & $\mathrm{HP}^{2}$ & 921.6 & 1,680 & 0.000243 & $(0.000)$ & 0.000243 & $(0.000)$ & \\
\hline \multirow{3}{*}{$\begin{array}{c}\text { Endogeneity } \\
\text { bias } \\
\text { correction } \\
\end{array}$} & $\begin{array}{l}\text { KEPT_UN* } \\
(1 \text { vs. } 0)\end{array}$ & 0.173 & 0.215 & 0.158 & $(0.000)$ & 0.560 & $(0.000)$ & $175 \%$ \\
\hline & \begin{tabular}{|l} 
FRAQ_KEPT** \\
\end{tabular} & 0.0315 & 0.0837 & -0.704 & $(0.000)$ & -2.367 & $(0.000)$ & \\
\hline & Constant & & & 7.349 & $(0.000)$ & 7.524 & $(0.000)$ & \\
\hline \multirow{3}{*}{$\begin{array}{c}\text { Test } \\
\text { statistics }\end{array}$} & $\mathrm{R}^{2}\left(\mathrm{R}^{2} \mathrm{aj}\right)$ & & & $\begin{array}{r}76.1 \% \\
(75.3 \%) \\
\end{array}$ & & $\begin{array}{r}64.4 \% \\
(63.1 \%) \\
\end{array}$ & & \\
\hline & $\mathrm{F}$ & & & 91.26 & $(0.000)$ & 60.37 & $(0.000)$ & \\
\hline & Sargan test & & & & & 1.364 & $(0.243$ & \\
\hline
\end{tabular}

247 higher prices (price index up to $118 \%$ ). The price of tuis increases with crew size, up to a point

248 (crew of 3) after which it decreases. Tui prices appear to be higher if they are composed of fish

249 caught with selective fishing gear such as line (price index up to 115\%) and motorized boats

250 such as poti marara (price index up to $142 \%$ ). The price of tuis also depends on the power of

251 the motors on boats, in the shape of a convex polynomial function with a minimum of $83 \mathrm{HP}^{15}$.

252 Hence, tui prices are higher when the fish have been caught either with small or unmotorized

\footnotetext{
${ }^{15} \ln (\widehat{P})=7.524-0.0403 H P+0.000243 H P^{2}$
} 
253 boats, or with boats with powerful motors. Tui prices are lower for fish caught with boats of 254 intermediate horsepower (80 HP).

\section{Implicit Price of the Most Frequent Species Groups}

256 To estimate the demand function with Equation 3, we first stratify our database to form 257 subsamples of tuis containing each species group. This stratification shows that the first 258 fourteen species groups in Table 1 (Scarus followed by Chlorurus, Parupeneus, Myripristis, 259 Mulloidichthys, Siganus, Pelagic taxa, Naso, Epinephelus, Acanthurus, Cephalopholis, 260 Sargocentron, Lutjanus and Selar) are the most abundant, representing $95.85 \%$ of the total 261 length of all the fish present on the 742 tuis. Only these species groups have large enough 262 subsamples to obtain reliable estimates. These fourteen species groups are ranked in Table 8 263 from right to left in descending order of the number of tuis in which they are encountered. The 264 size of these subsamples varies from 311 to 30 tuis. The most abundant species group is Scarus 265 (in 311 tuis) followed by Chlorurus (in 140 tuis) and Parupeneus (in 130 tuis), while Lutjanus 266 and Selar are rare (in 30 tuis only).

267 Tuis can contain up to nine different species groups and half of the sampled tuis (51.28\%) 268 contain at least two species groups. Table 8 shows the structure of species group combinations 269 on the tuis. Some species groups are more often combined for sale than others. Two species 270 groups, Pelagic taxa and Selar, are crossed with very few other species groups: Selar, present 271 in only 30 tuis is combined with two other species groups only (Lutjanus and Pelagic); 
Table 8. Species groups combinations on tuis

\begin{tabular}{|c|c|c|c|c|c|c|c|c|c|c|c|c|c|c|}
\hline & Scarus & Chlor. & Paru. & Myri. & Mull. & Siga. & Naso. & Epine. & Acan. & Ceph. & Sarg. & Lutj. & Pela. & Sela. \\
\hline Number of tuis & $311^{\mathrm{a}}$ & 140 & 130 & 115 & 108 & 104 & 85 & 73 & 58 & 55 & 52 & 30 & 90 & 30 \\
\hline Number of species groups & $27^{\mathrm{b}}$ & 21 & 25 & 28 & 27 & 24 & 21 & 22 & 21 & 21 & 24 & 20 & 4 & 2 \\
\hline Scarus & & $\begin{array}{c}122 \\
(0.87) \\
\end{array}$ & $\begin{array}{c}64 \\
(0.49) \\
\end{array}$ & $\begin{array}{c}18 \\
(0.16) \\
\end{array}$ & $\begin{array}{c}53 \\
(0.49) \\
\end{array}$ & $\begin{array}{c}22 \\
(0.21) \\
\end{array}$ & $\begin{array}{c}16 \\
(0.19) \\
\end{array}$ & $\begin{array}{c}26 \\
(0.36) \\
\end{array}$ & $\begin{array}{c}25 \\
(0.43) \\
\end{array}$ & $\begin{array}{c}23 \\
(0.42) \\
\end{array}$ & $\begin{array}{c}18 \\
(0.35) \\
\end{array}$ & $\begin{array}{c}12 \\
(0.4) \\
\end{array}$ & $\begin{array}{c}0 \\
(0.00) \\
\end{array}$ & $\begin{array}{c}0 \\
(0.00) \\
\end{array}$ \\
\hline Chlorurus & $\begin{array}{c}122^{\mathrm{c}} \\
\left(0.39^{\mathrm{d}}\right) \\
\end{array}$ & & $\begin{array}{c}22 \\
(0.17) \\
\end{array}$ & $\begin{array}{c}4 \\
(0.03) \\
\end{array}$ & $\begin{array}{c}15 \\
(0.14) \\
\end{array}$ & $\begin{array}{c}12 \\
(0.12) \\
\end{array}$ & $\begin{array}{c}8 \\
(0.09) \\
\end{array}$ & $\begin{array}{c}10 \\
(0.14) \\
\end{array}$ & $\begin{array}{c}10 \\
(0.17) \\
\end{array}$ & $\begin{array}{c}7 \\
(0.13) \\
\end{array}$ & $\begin{array}{c}4 \\
(0.08) \\
\end{array}$ & $6(0.2)$ & $\begin{array}{c}0 \\
(0.00) \\
\end{array}$ & $\begin{array}{c}0 \\
(0.00) \\
\end{array}$ \\
\hline Parupeneus & $\begin{array}{c}64 \\
(0.21) \\
\end{array}$ & $\begin{array}{c}22 \\
(0.16) \\
\end{array}$ & & $\begin{array}{c}19 \\
(0.17) \\
\end{array}$ & $\begin{array}{c}72 \\
(0.67) \\
\end{array}$ & $\begin{array}{c}20 \\
(0.19) \\
\end{array}$ & $\begin{array}{c}20 \\
(0.24) \\
\end{array}$ & $\begin{array}{c}26 \\
(0.36) \\
\end{array}$ & $\begin{array}{c}20 \\
(0.34) \\
\end{array}$ & $\begin{array}{c}20 \\
(0.36) \\
\end{array}$ & $\begin{array}{c}15 \\
(0.29) \\
\end{array}$ & $\begin{array}{c}10 \\
(0.33) \\
\end{array}$ & $\begin{array}{c}0 \\
(0.00) \\
\end{array}$ & $\begin{array}{c}0 \\
(0.00) \\
\end{array}$ \\
\hline Mulloidichthys & $\begin{array}{c}53 \\
(0.17) \\
\end{array}$ & $\begin{array}{c}15 \\
(0.11)\end{array}$ & $\begin{array}{c}72 \\
(0.55)\end{array}$ & $\begin{array}{c}14 \\
(0.12)\end{array}$ & & $\begin{array}{c}13 \\
(0.13) \\
\end{array}$ & $\begin{array}{c}10 \\
(0.12) \\
\end{array}$ & $\begin{array}{c}24 \\
(0.33)\end{array}$ & $\begin{array}{c}16 \\
(0.28)\end{array}$ & $\begin{array}{c}17 \\
(0.31)\end{array}$ & $\begin{array}{c}13 \\
(0.25) \\
\end{array}$ & $\begin{array}{c}7 \\
(0.23) \\
\end{array}$ & $\begin{array}{c}0 \\
(0.00) \\
\end{array}$ & $\begin{array}{c}0 \\
(0.00)\end{array}$ \\
\hline Epinephelus & $\begin{array}{c}26 \\
(0.08)\end{array}$ & $\begin{array}{c}10 \\
(0.07)\end{array}$ & $\begin{array}{c}26 \\
(0.2) \\
\end{array}$ & $\begin{array}{c}22 \\
(0.19)\end{array}$ & $\begin{array}{c}24 \\
(0.22)\end{array}$ & $\begin{array}{c}12 \\
(0.12)\end{array}$ & $\begin{array}{c}8 \\
(0.09)\end{array}$ & & $\begin{array}{c}14 \\
(0.24)\end{array}$ & $\begin{array}{c}40 \\
(0.73)\end{array}$ & $\begin{array}{c}16 \\
(0.31) \\
\end{array}$ & $\begin{array}{c}12 \\
(0.4)\end{array}$ & $\begin{array}{c}0 \\
(0.00)\end{array}$ & $\begin{array}{c}0 \\
(0.00)\end{array}$ \\
\hline Acanthurus & $\begin{array}{c}25 \\
(0.08) \\
\end{array}$ & $\begin{array}{c}10 \\
(0.07) \\
\end{array}$ & $\begin{array}{c}20 \\
(0.15) \\
\end{array}$ & $\begin{array}{c}13 \\
(0.11) \\
\end{array}$ & $\begin{array}{c}16 \\
(0.15) \\
\end{array}$ & $\begin{array}{c}16 \\
(0.15) \\
\end{array}$ & $\begin{array}{c}14 \\
(0.16) \\
\end{array}$ & $\begin{array}{c}14 \\
(0.19) \\
\end{array}$ & & $\begin{array}{c}10 \\
(0.18) \\
\end{array}$ & $\begin{array}{c}7 \\
(0.13) \\
\end{array}$ & $\begin{array}{c}4 \\
(0.13) \\
\end{array}$ & $\begin{array}{c}0 \\
(0.00) \\
\end{array}$ & $\begin{array}{c}0 \\
(0.00) \\
\end{array}$ \\
\hline Cephalopholis & $\begin{array}{c}23 \\
(0.07) \\
\end{array}$ & $\begin{array}{c}7 \\
(0.05) \\
\end{array}$ & $\begin{array}{c}20 \\
(0.15) \\
\end{array}$ & $\begin{array}{c}14 \\
(0.12) \\
\end{array}$ & $\begin{array}{c}17 \\
(0.16) \\
\end{array}$ & $9(0.09)$ & $\begin{array}{c}1 \\
(0.01) \\
\end{array}$ & $\begin{array}{c}40 \\
(0.55) \\
\end{array}$ & $\begin{array}{c}10 \\
(0.17) \\
\end{array}$ & & $\begin{array}{c}13 \\
(0.25) \\
\end{array}$ & $\begin{array}{c}5 \\
(0.17) \\
\end{array}$ & $\begin{array}{c}0 \\
(0.00) \\
\end{array}$ & $\begin{array}{c}0 \\
(0.00) \\
\end{array}$ \\
\hline Siganus & $\begin{array}{c}22 \\
(0.07)\end{array}$ & $\begin{array}{c}12 \\
(0.09)\end{array}$ & $\begin{array}{c}20 \\
(0.15)\end{array}$ & $\begin{array}{c}21 \\
(0.18)\end{array}$ & $\begin{array}{c}13 \\
(0.12)\end{array}$ & & $\begin{array}{c}17 \\
(0.2)\end{array}$ & $\begin{array}{c}12 \\
(0.16)\end{array}$ & $\begin{array}{c}16 \\
(0.28)\end{array}$ & $\begin{array}{c}9 \\
(0.16)\end{array}$ & $\begin{array}{c}14 \\
(0.27)\end{array}$ & $3(0.1)$ & $\begin{array}{c}2 \\
(0.02) \\
\end{array}$ & $\begin{array}{c}0 \\
(0.00)\end{array}$ \\
\hline Myripristis & $\begin{array}{c}18 \\
(0.06)\end{array}$ & $\begin{array}{c}4 \\
(0.03) \\
\end{array}$ & $\begin{array}{c}19 \\
(0.15)\end{array}$ & & $\begin{array}{c}14 \\
(0.13)\end{array}$ & $21(0.2)$ & $\begin{array}{c}17 \\
(0.2)\end{array}$ & $\begin{array}{c}22 \\
(0.3) \\
\end{array}$ & $\begin{array}{c}13 \\
(0.22)\end{array}$ & $\begin{array}{c}14 \\
(0.25)\end{array}$ & $\begin{array}{c}27 \\
(0.52) \\
\end{array}$ & $9(0.3)$ & $\begin{array}{c}1 \\
(0.01)\end{array}$ & $\begin{array}{c}0 \\
(0.00)\end{array}$ \\
\hline Sargocentron & $\begin{array}{c}18 \\
(0.06)\end{array}$ & $\begin{array}{c}4 \\
(0.03)\end{array}$ & $\begin{array}{c}15 \\
(0.12)\end{array}$ & $\begin{array}{c}27 \\
(0.23)\end{array}$ & $\begin{array}{c}13 \\
(0.12)\end{array}$ & $\begin{array}{c}14 \\
(0.13)\end{array}$ & $\begin{array}{c}5 \\
(0.06)\end{array}$ & $\begin{array}{c}16 \\
(0.22)\end{array}$ & $\begin{array}{c}7 \\
(0.12)\end{array}$ & $\begin{array}{c}13 \\
(0.24)\end{array}$ & & $3(0.1)$ & $\begin{array}{c}0 \\
(0.00)\end{array}$ & $\begin{array}{c}0 \\
(0.00)\end{array}$ \\
\hline Naso & $\begin{array}{c}16 \\
(0.05) \\
\end{array}$ & $\begin{array}{c}8 \\
(0.06) \\
\end{array}$ & $\begin{array}{c}20 \\
(0.15) \\
\end{array}$ & $\begin{array}{c}17 \\
(0.15) \\
\end{array}$ & $\begin{array}{c}10 \\
(0.09) \\
\end{array}$ & $\begin{array}{c}17 \\
(0.16) \\
\end{array}$ & & $\begin{array}{c}8 \\
(0.11) \\
\end{array}$ & $\begin{array}{c}14 \\
(0.24) \\
\end{array}$ & $\begin{array}{c}1 \\
(0.02) \\
\end{array}$ & $\begin{array}{c}5 \\
(0.1) \\
\end{array}$ & $6(0.2)$ & $\begin{array}{c}0 \\
(0.00) \\
\end{array}$ & $\begin{array}{c}0 \\
(0.00) \\
\end{array}$ \\
\hline Lutjanus & $\begin{array}{c}12 \\
(0.04) \\
\end{array}$ & $\begin{array}{c}6 \\
(0.04) \\
\end{array}$ & $\begin{array}{c}10 \\
(0.08) \\
\end{array}$ & $\begin{array}{c}9 \\
(0.08) \\
\end{array}$ & $\begin{array}{c}7 \\
(0.06) \\
\end{array}$ & $3(0.03)$ & $\begin{array}{c}6 \\
(0.07) \\
\end{array}$ & $\begin{array}{c}12 \\
(0.16)\end{array}$ & $\begin{array}{c}4 \\
(0.07) \\
\end{array}$ & $\begin{array}{c}5 \\
(0.09) \\
\end{array}$ & $\begin{array}{c}3 \\
(0.06) \\
\end{array}$ & & $\begin{array}{c}0 \\
(0.00) \\
\end{array}$ & $\begin{array}{c}2 \\
(0.07) \\
\end{array}$ \\
\hline Pelagic & $0(0.00)$ & $\begin{array}{c}0 \\
(0.00)\end{array}$ & $\begin{array}{c}0 \\
(0.00)\end{array}$ & $\begin{array}{c}1 \\
(0.01)\end{array}$ & $\begin{array}{c}0 \\
(0.00)\end{array}$ & $2(0.02)$ & $\begin{array}{c}0 \\
(0.00)\end{array}$ & $\begin{array}{c}0 \\
(0.00)\end{array}$ & $\begin{array}{c}0 \\
(0.00)\end{array}$ & $\begin{array}{c}0 \\
(0.00)\end{array}$ & $\begin{array}{c}0 \\
(0.00)\end{array}$ & $\begin{array}{c}0 \\
(0.00)\end{array}$ & & $\begin{array}{c}1 \\
(0.03)\end{array}$ \\
\hline Selar & $0(0.00)$ & $\begin{array}{c}0 \\
(0.00) \\
\end{array}$ & $\begin{array}{c}0 \\
(0.00) \\
\end{array}$ & $\begin{array}{c}0 \\
(0.00) \\
\end{array}$ & $\begin{array}{c}0 \\
(0.00) \\
\end{array}$ & $0(0.00)$ & $\begin{array}{c}0 \\
(0.00) \\
\end{array}$ & $\begin{array}{c}0 \\
(0.00) \\
\end{array}$ & $\begin{array}{c}0 \\
(0.00) \\
\end{array}$ & $\begin{array}{c}0 \\
(0.00) \\
\end{array}$ & $\begin{array}{c}0 \\
(0.00) \\
\end{array}$ & $\begin{array}{c}2 \\
(0.07) \\
\end{array}$ & $\begin{array}{c}1 \\
(0.01) \\
\end{array}$ & \\
\hline
\end{tabular}

Explanation of the data: $311^{\mathrm{a}}$ tuis contain Scarus (2nd line). Scarus is combined with $27^{\mathrm{b}}$ other species groups (3rd line). Scarus is combined with Chlorurus in $122^{\mathrm{c}}$ tuis, which corresponds to $39 \%$ of the subsample of 311 tuis of Scarus (the matrix). 
Pelagic taxa are sold with four other groups (Myripristis, Selar, Siganus and the unidentified species group). The other 12 species groups (in grey in Table 8) are often combined with a large number of other species groups (between 20 and 28 of the 37 species groups present in the market). For example, the most abundant species group, Scarus, is combined with 27 other species groups, while Myripristis is with 28 (Table 8, Line 3). The second most frequent species group, Chlorurus, is pooled on 122 tuis together with Scarus, but only on 4 tuis together with Myripristis. Note that Naso is combined with Cephalopholis only on one tui. This structure of species group combinations provides information on the degree of dependence between different groups in the composition of tuis.

To account for cross-species group elasticities within the same tui, we introduce in the model of each of these fourteen species groups, the lengths of the other species groups, as well as a binary indicator of their presence in individual tuis. However, the tuis in each sample do not contain all possible combinations with the other 37 species groups in the database. The most frequent combinations are only between the fourteen most frequent species groups and between a subset of these for some species groups. In the subsample of tuis of the most frequent species group, Scarus is combined with Chlorurus, Parupeneus, Mulloidichthys, Epinephelus, Acanthurus, Cephalopholis and Siganus in respectively 39\%, 21\%, 17\%, 8\%, 8\%, 7\% and 7\% of the 311 tuis. In estimating the model of the implicit price of Scarus, we only introduce these seven species groups in order to identify the corresponding parameters. We do the same for each of the other 14 species groups. Table 9 gives cross-elasticities for only those combinations of species groups that are observable and frequent enough among the tuis.

Using Rosen's second stage (Equation 3), we estimate the demand functions for the fourteen most abundant species groups (Table A1 in the supplementary material). We limit this analysis to these fourteen species groups, because they are the only ones with sufficient sample size. Additionally, the demand factors needed to identify these functions only have a discriminating 
effect for these fourteen species groups, with their parameters having statistically significant and reliable values. In estimating the demand functions, we also correct for the endogeneity problem of the explanatory variable FREQ_KEP, by the use of a double least squares estimation procedure (as in the hedonic price estimation), and for the problem of collinearity between the explanatory variables by stepwise elimination of variables with the highest VIF (all the factors in the estimated models have VIF values below the theoretical reference threshold of 5).

The length combinations of the fourteen species groups whose implicit price models are estimated allow us to identify the signs ${ }^{16}$ of cross-price elasticities between these groups (Table 9). These elasticities specify whether the species groups enter into the composition of tuis as complements (+) or substitutes (-). Results show that all the elasticities are positive between all reef species and negative between Pelagic taxa and two reef species, Selar and Siganus. except for two species groups: Pelagic taxa and Selar. Selar appear as a substitute group for Pelagic taxa only; This means that, except for Pelagic taxa which appear as a substitute group ${ }^{17}$ for Selar and Siganus, The other twelve all the reef species groups enter as complements in the composition of tuis: some with more species groups than others. Scarus is combined with ten other species groups; Parupeneus and Myripristis with eight; Epinephelus and Acanthurus with six; Mulloidichthys and Siganus with four; Chlorurus, Naso and Sargocentron with three; Lutjanus and Cephalopholis with two. Other interaction parameters are not statistically significant (according to Student's bilateral test): the underlying elasticities are therefore not important and the corresponding species groups appear to enter independently in the composition of tuis. Scarus, for example, is present independently of Lutjanus, Selar and Cephalopholis, which are rare species groups in our sample. These interactions reflect seller

\footnotetext{
${ }^{16}$ Price elasticity of species group $j$ with respect to a variation in the length of species group $k$ available on the tui is $e_{j / k}=$ $\beta_{k}^{j}+2 \beta_{k k}^{j} \ln \left(L^{k}\right)+\sum_{l \neq k}^{37} \beta_{k l}^{j} \ln \left(L^{l}\right)$. Given the flexible form of the implicit price equation, this elasticity is not constant, but its sign is easy to determine: it is equivalent to the sign of the parameters.

${ }^{17}$ We note in Tables 1 and 2 that Pelagic taxa are often sold alone: $24 \%$ of single species group tuis and only $12 \%$ of all the survey.
} 
strategies to enhance the value of the fish sold: where cross price elasticities exist, the species groups on offer value gain in the presence of other species groups, except in the case of Pelagic species (which are caught outside the lagoon and reef areas).

Table 9. Signs of cross-price elasticities between the 14 species groups

\begin{tabular}{l|c|c|c|c|c|c|c|c|c|c|c|c|c|c|c}
\hline Species groups & Sca. & Chl. & Par. & Myr. & Mul & Sig. & Pel. & Nas. & Epi. & Acan. & Cep. & Sar. & Lut. & Sel. & NI \\
\hline Scarus & & + & + & + & + & + & & + & + & + & & + & & & + \\
\hline Chlorurus & + & & & & + & & & & & + & & & & & \\
\hline Parupeneus & + & & & + & + & + & & + & & + & + & & + & & \\
\hline Myripristis & + & & + & & & + & & + & + & + & & + & + & & \\
\hline Mulloidichthys & + & + & + & & & & & & + & & & & & & \\
\hline Siganus & + & & + & + & & & - & & & + & & & & & \\
\hline Pelagic & & & & & & - & & & & & & & & - & \\
\hline Naso & + & & + & + & & & & & & & & & & & \\
\hline Epinephelus & + & & & + & + & & & & & + & + & + & & & \\
\hline Acanthurus & + & + & + & + & & + & & & + & & & & & & \\
\hline Cephalopholis & & & + & & & & & & + & & & & & & \\
\hline Sargocentron & + & & & + & & & & & + & & & & & & \\
\hline Lutjanus & & & + & + & & & & & & & & & & & \\
\hline Selar & & & & & & & - & & & & & & & & \\
\hline
\end{tabular}

Using the estimated demand function of the fourteen most abundant species groups, we calculated their prices according to Equation 4. The results are illustrated in Figure 2, for eleven of the reef-associated species groups ${ }^{18}$.

Figure 1a shows the price-index of these species groups relative to the price of the most frequent taxon encountered in the survey (Scarus). The results highlight strong heterogeneity in the market value across species groups, which varies between 133 and 137 per cent of the market value of Scarus. The next most abundant species groups in this market (Parupeneus, Myripristis and Mulloidichtys) have high market value, with a price index varying between 120 and 135 per cent. Acanthurus and Sargocentron display high price indices (respectively 137 and 133 per cent), but are encountered less frequently in the tuis.

\footnotetext{
${ }^{18}$ Excluding Chlorurus which appeared as an outlier in the price distribution with a price index of $479 \%$. This may have been due to the heterogeneity of the species group, and observation biases.
} 
When applied to the average size of individuals encountered in each species group ${ }^{19}$, prices derived from Equation 4 provide an estimation of the minimum, mean and maximum price one would pay for a single fish of each species group (Figure 1b). The four species groups

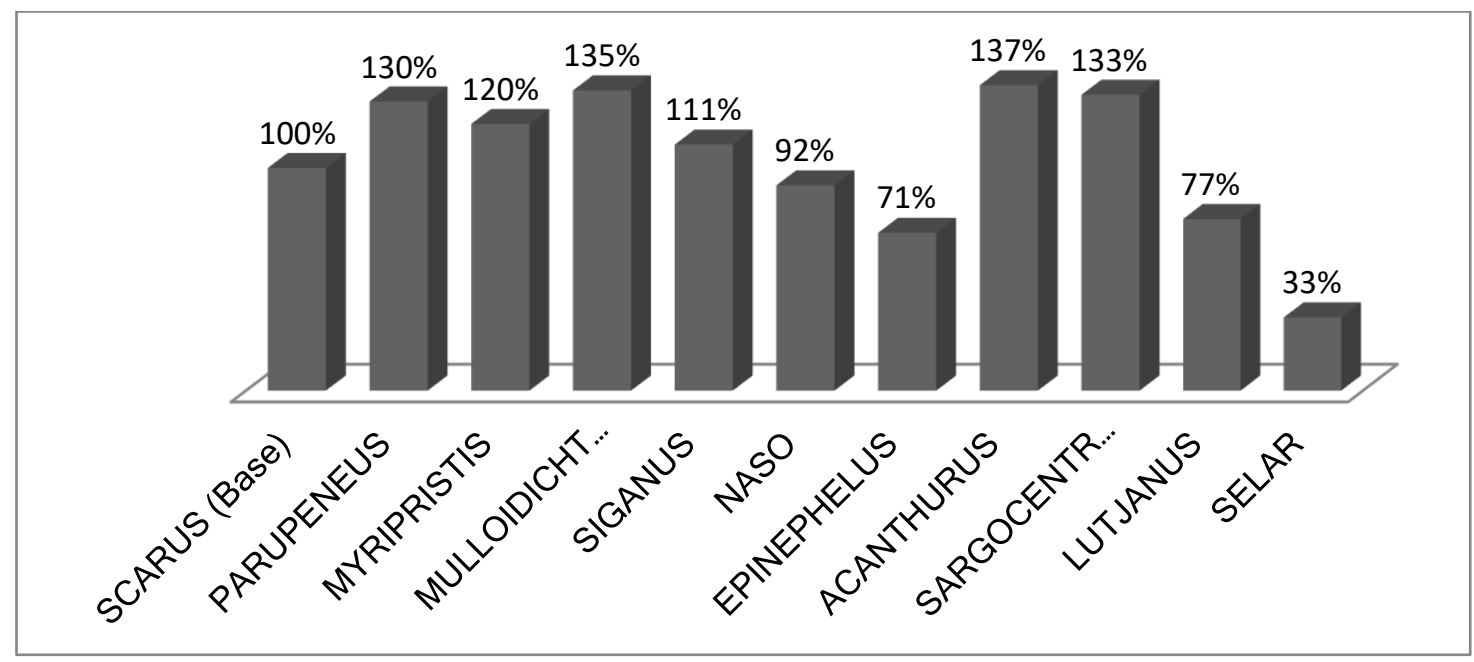

(a) Price index of coral reef fish species groups (based on Scarus)

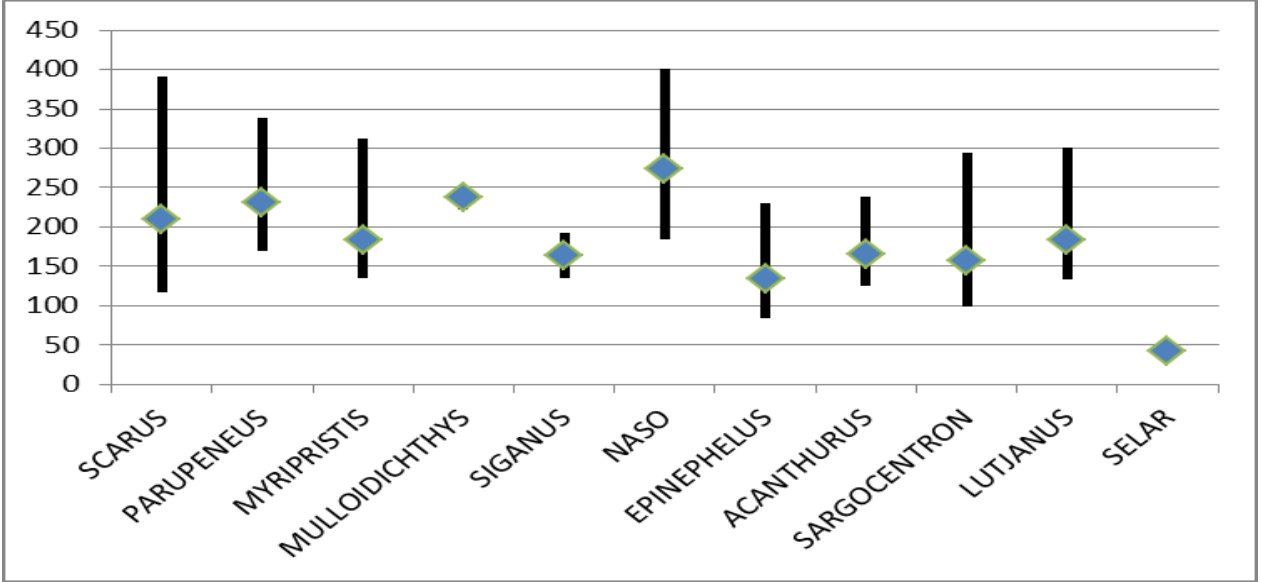

(b) Price in CFP of mean (min and max)-size fish per species group

Figure 1. Price estimation results for most frequent coral-reef fish species groups

(Species groups are ranked left to right from most to less frequently encountered in the survey)

most frequently encountered on tuis (Scarus, Parupeneus, Myripristis and Mulloidichthys) still appear to be the more valuable (with prices/fish of between 184 and 237 CFP for an additional medium-sized fish measuring between 35.42 and $48.25 \mathrm{~cm}$ ). Naso display the highest prices per fish (274 CFP for a medium-sized fish of $68.50 \mathrm{~cm}$ ), and is not frequently encountered in the tuis (Table 1). All the other species groups, which are less frequently encountered on this

\footnotetext{
${ }^{19}$ See Table A2 in the Appendix for data regarding average fish sizes of each species. The medium size of individual fish across all species groups varies between 27.17 and $68.50 \mathrm{~cm}$.
} 
market, present lower prices/fish piece (under $184 \mathrm{CFP} /$ fish of medium size varying between 27.17 and $53 \mathrm{~cm}$ ). Selar and Pelagic taxa present very low prices, in addition to being rare in the composition of tuis.

\section{Discussion and Conclusion}

This research examines the extent to which economic analysis can help explain the patterns of fish sales and fish prices observed in the coral reef fin-fish fishery of Moorea, French Polynesia. We used the data collected in a survey of roadside tui sales around the island to assess the factors contributing to the price at which the tuis are sold, and to deduce the implicit price of different species groups entering in their composition. Our results show that different groups of reef fish attract implicit prices that may vary by a factor of four to five across species groups. In addition to certain species groups, factors that entail higher prices for tuis include a seasonal dimension (higher prices being fetched during the first half of the calendar year), as well as the fishing techniques and other characteristics of the fishing trips such as the size of the crew. Ciguatera risk, by contrast, did not seem to account for price differences between species groups. Furthermore, our results highlight positive cross-price elasticities between many coral reef species groups. In other words, this means that sellers develop strategies to enhance the value of their daily catches through the species mix (except in the case of Pelagic taxa, that are caught outside the lagoon and reef areas).

This fish market can be considered transparent, since the sellers catch the fish they offer close to sale outlets, using local fishing techniques. However, the quality of the fish and therefore their price can also depend on other criteria (that were not measured in the survey). For example, the appearance of fish was not documented in the survey. Data on the physical quality of fish sold, such as traces of handling or state of freshness, are notoriously difficult to observe and measure. Attributes such as the presence of marks due to the fishing method could affect the 
perception of the quality of fish offered on tuis, leading to bias in the measurement of their implicit prices (Pope 2008).

Despite these limitations, the results of this analysis illustrate that market processes can help explain the composition and relative prices of tuis offered in roadside sales in coral reef fishery. Taking the observed price differences as a reflection of the preferences of local consumers and associated demand for fish, the results can also be used to assess the economic implications of changes in the supply of the different species groups, such as would result from changes in the abundance and accessibility of these groups to fishers around the island. In particular, Moorea has undergone strong environmental disturbance in its recent past due to the detrimental impacts of blooms of a coral predator sea star and cyclones (Lamy et al. 2016). Although most of the effects on fish resulted in biomass transfer within functional groups (Lamy et al. 2015), the marine ecosystems presented a recovery debt (Dubois et al. 2019) and understanding how fishermen respond and adapt, and how this translate into changes into how fish are sold remain unresolved..

In addition, the results provide important information on the status of the market for fish on the island. Fish buyers are willing to pay more for extra quantities of fish. This implies that the demand is not completely met by the supply of fish from the local fishery. Besides, the fish demand is expected to grow with an increasing number of new inhabitants less involved in fishing activities themselves (Thiault et al. 2018b). Provided the local fish resources enable additional catch and landings, this market would be expected to expand over time.

Finally, our results show how these fishers value their coral reef fish species on a local and direct sale market. This should be complemented by an analysis of the costs of fishing to gain a comprehensive economic perspective of small-scale fishing activities in Moorea. Beyond this case study, the research also illustrates how empirical economic research can help improve the understanding of small-scale coral-reef fisheries, and demonstrates a methodology which can 
be applied to a broad range of contexts in the Pacific, where these fisheries have particularly strong social and cultural value, provided similar data on fish sales is available.

\section{References}

Aubanel, Annie. 1993. «Evaluation socio-économique de la pêche en milieu corallien dans l'île de Moorea ». Journal de la Société des océanistes 96 (1): 49-62. https://doi.org/10.3406/jso.1993.2920.

Audras, Frédéric, Tamatoa Bambridge, et François Gaulme. 2017. « La République, le Pays et le Tavana », janvier, 218.

Bellwood, D. R., A. S. Hoey, et T. P. Hughes. 2012. « Human Activity Selectively Impacts the Ecosystem Roles of Parrotfishes on Coral Reefs ». Proceedings of the Royal Society B: Biological Sciences 279 (1733): 1621-29. https://doi.org/10.1098/rspb.2011.1906.

Berndt, Ernst R., et Laurits R. Christensen. 1973. « The Translog Function and the Substitution of Equipment, Structures, and Labor in U.S. Manufacturing 1929-68 ». Journal of Econometrics 1 (1): 81-113. https://doi.org/10.1016/0304-4076(73)90007-9.

Bonanno, Alessandro, Francesco Bimbo, Marco Costanigro, Alfons Oude Lansink, et Rosaria Viscecchia. 2019. «Credence Attributes and the Quest for a Higher Price - a Hedonic Stochastic Frontier Approach ». European Review of Agricultural Economics 46 (2): 163-92. https://doi.org/10.1093/erae/jby024.

Carroll, Michael T., James L. Anderson, et Josué Martínez-Garmendia. 2001. «Pricing U.S. North Atlantic Bluefin Tuna and Implications for Management: North Atlantic Bluefin Tuna ». Agribusiness 17 (2): 243-54. https://doi.org/10.1002/agr.1014.

Cinner, Joshua. 2014. "Coral Reef Livelihoods». Current Opinion in Environmental Sustainability 7 (avril): 65-71. https://doi.org/10.1016/j.cosust.2013.11.025.

Farber, Stephen. 1998. «Undesirable Facilities and Property Values: A Summary of Empirical Studies ». Ecological Economics 24 (1): 1-14. https://doi.org/10.1016/S09218009(97)00038-4.

Freeman, A. Myrick, Joseph A. Herriges, et Catherine L. Kling. 2014. The measurement of environmental and resource values: theory and methods. Third edition. Abingdon, Oxon; New York, NY: RFF Press.

Griliches, Zvi. 2013. Price Indexes and Quality Change: Studies in New Methods of Measurement. Cambridge MA: HUP. http://public.eblib.com/choice/publicfullrecord.aspx?p=3047628.

Hammarlund, Cecilia. 2015. «The Big, the Bad, and the Average: Hedonic Prices and Inverse Demand for Baltic Cod». Marine Resource Economics 30 (2): 157-77. https://doi.org/10.1086/679972.

Heckman, James J., Rosa L. Matzkin, et Lars Nesheim. 2010. «NONPARAMETRIC IDENTIFICATION AND ESTIMATION OF NONADDITIVE HEDONIC MODELS ». Econometrica 78 (5): 1569-91.

Jensen, Gail A., et Michael A. Morrisey. 1990. «Group Health Insurance: A Hedonic Price Approach ». The Review of Economics and Statistics 72 (1): 38. https://doi.org/10.2307/2109737.

Johannes, R. E. 1981. Words of the Lagoon: Fishing and Marine Lore in the Palau District of Micronesia. Berkeley: University of California Press.

Karamti, Chiraz. s. d. "Indices de prix pour les services de la téléphonie mobile en France: Application de la méthode des prix Hédoniques », 402. 
Kumbhakar, Subal C., et Christopher F. Parmeter. 2010. «Estimation of Hedonic Price Functions with Incomplete Information ». Empirical Economics 39 (1): 1-25. https://doi.org/10.1007/s00181-009-0292-8.

Larkin, S. L., et G. Sylvia. 1999. «Intrinsic Fish Characteristics and Intraseason Production Efficiency: A Management-Level Bioeconomic Analysis of a Commercial Fishery ». American Journal of Agricultural Economics $81 \quad$ (1): 29-43. https://doi.org/10.2307/1244448.

Lauer, Matthew, et Shankar Aswani. 2009. «Indigenous Ecological Knowledge as Situated Practices: Understanding Fishers' Knowledge in the Western Solomon Islands ». American Anthropologist 111 (3): 317-29. https://doi.org/10.1111/j.15481433.2009.01135.x.

Leenhardt, Pierre, Matthew Lauer, Rakamaly Madi Moussa, Sally J. Holbrook, Andrew Rassweiler, Russell J. Schmitt, et Joachim Claudet. 2016. "Complexities and Uncertainties in Transitioning Small-Scale Coral Reef Fisheries ». Frontiers in Marine Science 3 (mai). https://doi.org/10.3389/fmars.2016.00070.

Leenhardt, Pierre, et Rakamaly Madi Moussa. 2012. «Quel est le rendement de la pêche récifolagonaire à Moorea? Synthèse des différentes données obtenues », 9.

Léopold, Marc, Olivier Thébaud, et Anthony Charles. 2019. «The Dynamics of Institutional Innovation: Crafting Co-Management in Small-Scale Fisheries through Action Research». Journal of Environmental Management 237 (mai): 187-99. https://doi.org/10.1016/j.jenvman.2019.01.112.

Mäler, Karl-Göran, et Jeffrey R. Vincent, éd. 2005. Handbook of Environmental Economics. ... Handbook of Environmental Economics: Valuing Environmental Changes; Volume 2. Handbooks in Economics 20. Amsterdam Boston: Elsevier.

Maslianskaïa-Pautrel, Masha. 2009. «La valorisation de la qualité de l'air par l'approche hédonique : une revue de la littérature ». Revue française d'économie 23 (3): 109-60. https://doi.org/10.3406/rfeco.2009.1738.

McConnell, Kenneth E., et Ivar E. Strand. 2000. « Hedonic Prices for Fish: Tuna Prices in Hawaii ». American Journal of Agricultural Economics 82 (1): 133-44. https://doi.org/10.1111/0002-9092.00011.

McManus, J. W. 1997. «Tropical marine fisheries and the future of coral reefs: a brief review with emphasis on Southeast Asia». Coral Reefs 16 (5): S121-27. https://doi.org/10.1007/s003380050248.

Morin, Ewen, Clémence Gatti, Tamatoa Bambridge, et Mireille Chinain. 2016. « Ciguatera Fish Poisoning: Incidence, Health Costs and Risk Perception on Moorea Island (Society Archipelago, French Polynesia)». Harmful Algae 60 (décembre): 1-10. https://doi.org/10.1016/j.hal.2016.10.003.

Moussa, Rakamaly MADI. 2010. «Estimation de la taille des poissons lagonaires vendus sous la forme de tuil en bord de route sur l'île de Moorea (Polynésie française) par analyse de clichés numériques », 10.

Nielsen, Jette, Grethe Hyldig, et Erling Larsen. 2002. " 'Eating Quality' of Fish-A Review ». Journal of Aquatic Food Product Technology 11 (3-4): 125-41. https://doi.org/10.1300/J030v11n03_10.

Pope, Jaren C. 2008. « Fear of Crime and Housing Prices: Household Reactions to Sex Offender Registries ». Journal of Urban Economics 64 (3): 601-14. https://doi.org/10.1016/j.jue.2008.07.001.

Rassweiler, Andrew, Matthew Lauer, Sarah E. Lester, Sally J. Holbrook, Russell J. Schmitt, Rakamaly Madi Moussa, Katrina S. Munsterman, et al. 2019. «Perceptions and Responses of Pacific Island Fishers to Changing Coral Reefs ». Ambio, mars. https://doi.org/10.1007/s13280-019-01154-5. 
Roka, Fritz M., et Raymond B. Palmquist. 1997. «Examining the Use of National Databases in a Hedonic Analysis of Regional Farmland Values ». American Journal of Agricultural Economics 79 (5): 1651. https://doi.org/10.2307/1244397.

Rosen, Sherwin. 1974. «Hedonic Prices and Implicit Markets: Product Differentiation in Pure Competition». Journal of Political Economy 82 (1): 34-55. https://doi.org/10.1086/260169.

Shimose, Tamaki, Minoru Kanaiwa, et Atsushi Nanami. 2019. «Influence of the Flesh Quality and Body Size on the Auction Price of Parrotfishes (Scaridae) at Tropical Island, Southern Japan: Implications for Fisheries Management ». Regional Studies in Marine Science 25 (janvier): 100489. https://doi.org/10.1016/j.rsma.2018.100489.

Thiault, Lauric, Antoine Collin, Frédérique Chlous, Stefan Gelcich, et Joachim Claudet. 2017. «Combining Participatory and Socioeconomic Approaches to Map Fishing Effort in Small-Scale Fisheries ». Édité par Sebastian C. A. Ferse. PLOS ONE 12 (5): e0176862. https://doi.org/10.1371/journal.pone.0176862.

Vignes, Annick, et Jean-Michel Etienne. 2011. «Price Formation on the Marseille Fish Market: Evidence from a Network Analysis ». Journal of Economic Behavior \& Organization 80 (1): 50-67. https://doi.org/10.1016/j.jebo.2011.07.003.

Yonger M., 2002. Approche de la pêcherie récifo-lagonaire de Moorea (Polynésie française) : évaluation de la production halieutique et de la population de pêcheurs. Mémoire de D.A.A. ENSA Rennes. 